BANCA D'ITALIA

E U R O S I S T E M A

Questioni di Economia e Finanza

(Occasional Papers)

Repo market and leverage ratio in the euro area.

by Luca Baldo, Eilipposasqualone and Antonio-Scalia

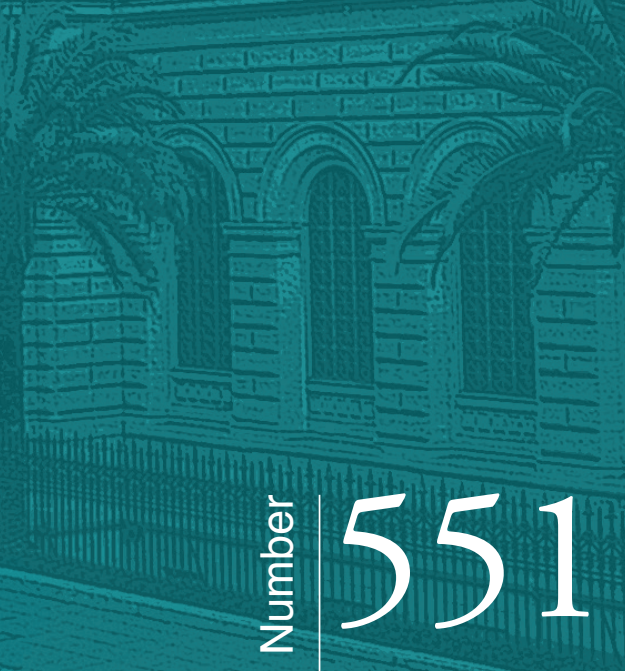



13 BANCA D'ITALIA

E U ROS I S T E M A

\section{Questioni di Economia e Finanza}

(Occasional Papers)

Repo market and leverage ratio in the euro area

by Luca Baldo, Filippo Pasqualone and Antonio Scalia

Number 551 - March 2020 
The series Occasional Papers presents studies and documents on issues pertaining to the institutional tasks of the Bank of Italy and the Eurosystem. The Occasional Papers appear alongside the Working Papers series which are specifically aimed at providing original contributions to economic research.

The Occasional Papers include studies conducted within the Bank of Italy, sometimes in cooperation with the Eurosystem or other institutions. The views expressed in the studies are those of the authors and do not involve the responsibility of the institutions to which they belong.

The series is available online at wwm. bancaditalia.it.

ISSN $1972-6627$ (print)

ISSN 1972-6643 (online)

Printed by the Printing and Publishing Division of the Bank of Italy 


\title{
REPO MARKET AND LEVERAGE RATIO IN THE EURO AREA
}

\author{
by Luca Baldo, Filippo Pasqualone and Antonio Scalia*
}

\begin{abstract}
This paper provides new evidence on the effect of the leverage ratio (LR) on repo market activity in the euro area. The share of trades with central counterparties has increased in recent years as a result of greater regulatory efficiency. After controlling for factors that may affect participation in the repo market, banks are found to exert market power towards non-bank financial institutions by applying lower rates and larger bid-ask spreads. While there is a permanent rate differential between transactions conducted via CCPs - which can easily be netted for LR purposes - and those with non-banks, on average this differential and the bidask spread do not increase at quarter-end. The widening of the bid-ask spread at year-end is sizeable, but this is not necessarily due to the LR, since other important factors enter into play. This evidence lessens the concern that the additional LR reporting and disclosure requirements based on daily averages, which will take effect on June 2021, might cause a contraction in repo volume and greater rate dispersion.
\end{abstract}

JEL Classification: E4, E5, G2.

Keywords: repo market, leverage ratio, monetary policy transmission.

DOI: $10.32057 / 0 . Q E F .2020 .551$

\section{Contents}

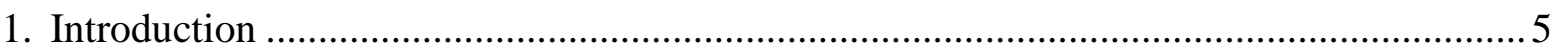

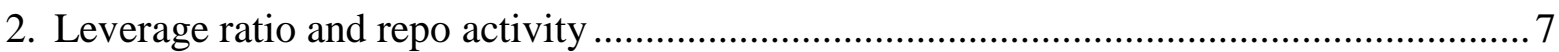

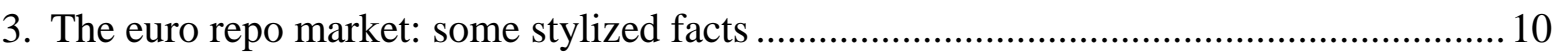

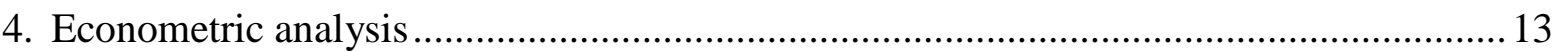

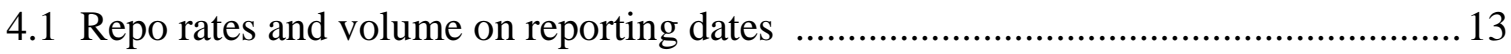

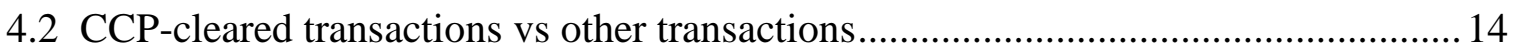

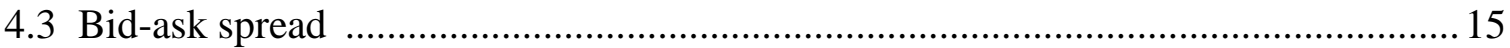

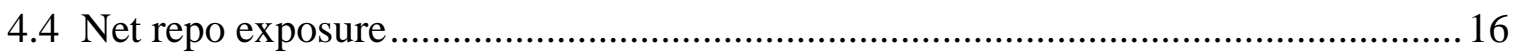

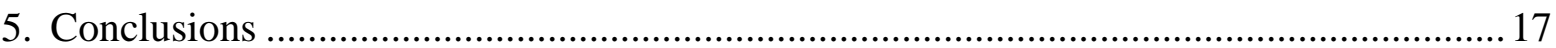

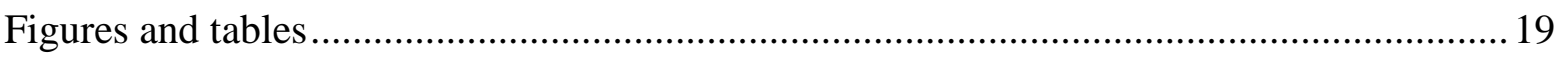

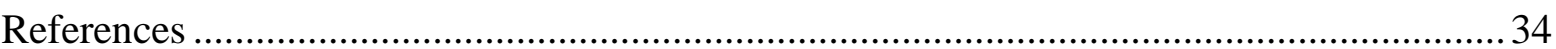

\footnotetext{
* Bank of Italy, Market Operations Directorate.
} 



\section{Introduction ${ }^{1}$}

The repo market, a fundamental vehicle for banks' funding, has grown in importance as a channel for monetary policy transmission in the euro area following the drop in unsecured money market activity caused by the global financial crisis (Grill et al., 2017). The repo market is also where the interactions between monetary policy implementation and regulatory requirements are most likely to materialize (CGFS, 2015). In particular, the leverage ratio (LR), a non-risk-weighted capital requirement, imposes a capital cost on low-margin and low-risk activities, such as repo trading. As a consequence, LRconstrained repo dealers may widen their bid-ask spread in order to compensate for the balance sheet cost embedded in repo transactions, thus increasing the dispersion of short-term money market rates and reducing the pass-through efficiency of monetary policy (Duffie and Krishnamurthy, 2016). These concerns also apply to monetary policy implementation in the euro area, where the increasing level of excess liquidity brought about by the Eurosystem asset purchase programme (APP) has fuelled the divergence of short-term interest rates (Coeuré, 2018). Part of the motivation is the window-dressing carried out by banks that tend to reduce their exposure at quarter-end when they report the LR, in order to appear less leveraged and safer (BIS, 2018). This in turn spills over into broader repo market liquidity issues that have attracted the attention of monetary and regulatory authorities.

In October 2018, the Basel Committee on Banking Supervision addressed the issue of window-dressing behaviour around LR reporting dates, stating that 'Window-dressing by banks is unacceptable, as it undermines the intended policy objectives of the leverage ratio requirement and risks disrupting the operations of financial markets' and suggested that supervisors take action against window-dressing activities (BCBS, 2018). In May 2019, the European Parliament finalized the amendments to the EU legislative framework on prudential requirements for banks and financial institutions, the 'CRR-II/CRDV package' (EU Parliament, 2019a, 2019b), which includes the steady state implementation of the LR in the EU. These amendments include measures to mitigate LR-related window-dressing behaviour by means of additional reporting and disclosure requirements based on average calculation over the reporting period. Although this provision falls short of imposing strict LR fulfilment on an average basis, ${ }^{2}$ it is still likely to increase scrutiny by supervisors and exert peer pressure. Thus the new rule, which will take effect in June 2021, may potentially have an impact on the functioning of the euro repo market.

\footnotetext{
${ }^{1}$ The views expressed in this paper are those of the authors and do not necessarily reflect those of the Bank of Italy. We would like to thank Emmanuelle Assouan, Annalisa Bucalossi, P. Olivier Cousseran, Paolo Del Giovane, Julija Jakovicka, Jan Kakes, Tiziana Rosolin, Karsten Stroborn and seminar participants at the ECB and Banca d'Italia for their useful comments. We are particularly grateful to Carla Stamegna and Vincenzo Capone for their valuable insights into the legislative process for the revision of the EU regulatory framework on banks' prudential requirements.

${ }^{2}$ It only features as a reporting and disclosure obligation, complemented by Pillar 2 measures where necessary, and not as a Pillar 1 requirement.
} 
This paper examines the effect of the leverage ratio on repo market activity in the euro area in recent years. We look in particular at the behaviour of banks, investigating the extent to which they adjust volume, the bid-ask spread and interest rates on cash borrowing transactions to compensate for their LRinduced balance sheet cost. The analysis of banks' behaviour around reporting dates may provide useful insights into the likely developments in the repo market once the LR is also measured on an average basis, and into the possible impact on the pass-through of monetary policy via short-term rates.

The existing evidence in the US and UK lends support to the theory that the LR has significant effects on repo market liquidity and generates window-dressing (Munyan, 2017; Allahrakha, Cetina and Munyan, 2018; Bicu et al., 2017; and Anbil and Senyuz, 2018), although in the UK the effects in terms of lower rates and reduced repo volume are borne by smaller clients, while larger clients with stronger relationships are virtually unaffected (Kotidis and van Horen, 2018).

In the euro area, the available evidence shows that between 2013 and 2014, repo market activity was almost unaffected by LR concerns outside of the reporting dates (Baldo, Bucalossi and Scalia, 2018). Quarterly balance sheet figures show a negative relationship between the level of the LR and the share of repo volume over the total 'exposure measure' (i.e. the denominator of the leverage ratio; Grill et al., 2017). Although statistically significant, this result is not economically sizeable. ${ }^{3}$ The observed differences in repo rates between contracts cleared with central counterparties (CCPs) and those that are cleared bilaterally reveal a preference for the former type of clearing, because it allows for the netting of exposures under the LR framework (Coeuré, 2017). ${ }^{4}$

In this paper, we update and extend earlier analyses on the effect of the leverage ratio on repo market activity in the euro area. For this purpose, we use detailed transaction data obtained as part of the ECB Money Market Statistical Reporting (MMSR) Regulation from 50 banks located in nine euro-area countries between July 2016 and December 2018. Besides the LR requirement, several factors normally interplay in euro repo markets, such as differences in collateral risk, cash and repo market liquidity, collateral specialness, trading platforms, and so on. The collateral jurisdiction is arguably the single most important determinant of rate dispersion on reporting dates. While we do not specifically examine these effects in this paper, we control for a large number of them and focus instead on the effect of the leverage ratio of individual institutions in order to derive some preliminary indications on possible market developments related to the LR regulation.

We show that the share of trades with CCPs steadily increased in the sample period, largely as a result of their greater capital cost-efficiency. Furthermore, we document novel aspects of the behaviour of

\footnotetext{
${ }^{3}$ The reasons for the limited effect of the LR on the repo market in the euro area vis-à-vis the United States are the following: i) the less advanced stage of implementation of the LR; ii) point-in-time reporting for European banks, which stimulates window dressing; and iii) greater reliance on CCP clearing, which facilitates the offsetting of transactions between agents.

${ }^{4}$ Repo and reverse repo can be netted if both the counterparties and the settlement dates coincide.
} 
euro-area banks, and notably a permanent rate differential between CCP-cleared repo trades and those made bilaterally with a non-bank or another bank. This measure of the 'true' interest rate differential does not change at quarter-end and it is not affected by the LR level of the reporting bank. Similarly, after controlling for other relevant factors, the bid-ask spread on repo transactions at quarter-end is not affected by the LR, while it generally widens at year-end because of other factors that we cannot measure separately. As for repo market turnover, at quarter-end we observe a significant decline in those CCPcleared transactions that may not benefit from the netting of exposures under the LR framework.

The above findings have some general implications. First, we document the market power of banks in relation to non-bank intermediaries, which do not have access to the central bank balance sheet and may only place their ample liquid funds with the banking system. Second, we show how flexibly banks adjust their repo trading with CCPs. Third, other factors in addition to the LR cause an increase at year-end in the compensation required for repo exposure.

Based on this evidence, although preliminary, we do not share the concerns raised by some researchers and practitioners that the future LR calculation on the basis of quarterly averages might cause a significant contraction in volume and greater rate dispersion in the euro repo market. We would instead expect repo business to continue their trend towards efficient exposure netting via CCP-clearing services, while the share of bilateral transactions with non-bank financial intermediaries may progressively decline, as a consequence of the potential growth in direct clearing with CCPs by nonbank intermediaries ${ }^{5}$ and in the event of a decline in excess liquidity.

The remainder of the paper is organized as follows. Section 2 reviews the LR standard and outlines its potential implications for banks' behaviour in the repo market. Section 3 describes the MMSR dataset and shows some stylized facts on the euro repo market. Section 4 reports the econometric analysis on volume, interest rates, bid-ask spread and exposure. Section 5 concludes.

\section{Leverage ratio and repo activity}

The Basel III leverage ratio was introduced in December 2010 by the Basel Committee on Banking Supervision (BCBS) in order to restrict the build-up of leverage in the banking sector, to avoid destabilizing deleveraging processes and to reinforce the risk-based capital ratios with a simple and nonrisk based backstop (BCBS, 2014). It is computed as the ratio between Tier 1 capital and an exposure measure that takes into account: (i) on-balance sheet exposures, (ii) derivative exposures, (iii) securities financing transaction exposures, and (iv) off-balance sheet items. In addition to a minimum capital requirement that banks must meet at all times (Pillar 1), the LR standard also comprises a set of public

\footnotetext{
${ }^{5}$ In 2016 and 2017, some European clearing houses (e.g. Eurex, LCH) started offering direct access to repo clearing services also to non-bank intermediaries.
} 
disclosure requirements (Pillar 3) whereby banks must report the leverage ratio on a quarter-end basis (BCBS, 2018).

In the European Union, the Commission Delegated Regulation (EU) 2015/62 set the requirement at 3 per cent and established it as a mandatory requirement as of 1 January 2018. However, international banks have been required to publicly disclose their LR level measured according to quarter-end figures since 1 January 2015. In November 2016, a proposal of the European Commission to amend the Capital Requirements Directive and Regulation (including the leverage ratio rule) was issued. As well as postponing the establishment of the leverage ratio as a mandatory requirement after 2018, it provided for the possibility of introducing an additional surcharge to the 3 per cent requirement for Global Systemically Important Financial Institutions (G-SIFIs). At the end of 2018, and with the endorsement of the Council of the European Union, a political agreement was reached on the comprehensive legislative package, which also includes the LR provisions. The final texts were adopted in May and published in the Official Journal in June 2019, making the LR rule effective from June 2021.

In the repo market, the impact of the leverage ratio may be material for cash borrowing transactions. Collateral encumbered under repo transactions remains on the balance sheet of the bank borrowing cash. At the same time, borrowed cash increases the size of the balance sheet, and correspondingly the exposure measure. Conversely, a reverse repo transaction (cash lending) is broadly neutral in terms of balance sheet size, as the cash lent on the asset side is replaced by the reverse repo claim. However, cash receivables and cash payables with the same counterparty can be measured on a net basis if the settlement date is the same. This means that exposures with the same CCP are netted out if they settle on the same date, hence they do not carry a balance sheet cost linked with the leverage ratio rule.

Recent data from the European Banking Authority (EBA, 2018) show that in the European Union the average leverage ratio was 5.3 per cent at the end of 2018, marginally lower than 5.4 per cent as of the end of 2017. The vast majority of banks in the European Union were above the 3 per cent regulatory threshold.

The formulation of the leverage ratio framework in the European Union establishes that banks are required to report quarter-end figures, while for instance US banks are required to report daily average figures on a quarterly basis. This creates incentives for banks to window dress their balance sheets ahead of reporting dates. In other words, banks may temporarily reduce their exposures in the financial markets, including the repo market, around reference dates with the aim of reporting a higher leverage ratio. The reduction of exposures may also affect repo rates. Banks borrowing in the repo market at reporting dates would require higher compensation in order to cover the balance sheet cost associated with the repo activity, with downward pressure on rates at quarter-end. Additional factors may further incentivize window-dressing at year-end, such as the G-SIB score assessment (Behn et al., 2019), the contribution to the Single Resolution Fund and other levies computed on the basis of banks' balance 
sheet size ${ }^{6}$ at the end of the fiscal year (Grill et al., 2017). For example, among the bank levies applied at national level, the German bank levy is computed on the basis of total liabilities net of equity and customer deposits derived from the annual balance sheet of the previous year (Buch et al., 2016).

Banks' window-dressing behaviour relating to the leverage ratio framework was heavily criticized in a newsletter published in October 2018 by the BCBS, which was followed by a public consultation on potential revisions to the LR disclosure requirements. ${ }^{7}$ After the public consultation, the BCBS agreed in June 2019 that internationally active banks must disclose part of the exposure measure, including repo activity, based on quarter-end values as well as on an average of daily values over the quarter. They also must disclose total leverage exposure and leverage ratio values as calculated using these average values. ${ }^{8}$

The European legislators addressed this issue in the final text amending the Capital Requirement Directive and Regulation published in June 2019. It is foreseen that, in addition to the 3 per cent leverage ratio minimum capital requirement, reported according to quarter-end figures, large institutions (as defined in the regulation) shall report specific components of the leverage ratio to their competent authorities based on averages over the reporting period and the data used to calculate those averages. In addition, large institutions shall also disclose their leverage ratio and the breakdown of the total exposure measure based on averages over the reporting period. ${ }^{9}$ These new provisions, effective from June 2021, might affect euro repo market conditions.

\footnotetext{
${ }^{6}$ Since 1 January 2016, credit institutions in the euro area are required to participate in the Single Resolution Fund with annual contributions whose amount is determined on the basis of the size and riskiness of their balance sheets. Moreover, a number of resolution regimes in place in some euro-area jurisdictions are financed with bank levies determined on the basis of the amount of banks' liabilities at year-end.

${ }^{7}$ In particular, the Committee proposes that banks be required to include in their Pillar 3 disclosures, in addition to the current requirements, the amounts of some exposures calculated based on an average of daily values over the quarter. However, the Committee also states that 'it will also continue to consider whether amendments to leverage ratio Pillar 1 calculation requirements would be appropriate to mitigate window-dressing behaviours' (BCBS, 2018)

8 'The Committee has agreed that internationally active banks must disclose the amounts of adjusted gross securities financing transaction (SFT) assets (as defined in paragraph 51(i) of the leverage ratio standard) based on quarter-end values and on an average of daily values over the quarter as part of their Pillar 3 requirements, in addition to disclosure of the total leverage exposure and the leverage ratio as calculated using the averaged value of SFTs. Given the heightened volatility in SFT markets around quarter-end dates, the disclosure of banks' average SFT exposures during the quarter will provide stakeholders with additional information relating to banks' actual leverage' (BCBS, 2019).

${ }^{9}$ In particular, article 430(1) of Regulation (EU) 2019/876 (CRR II) states that: 'in addition to the reporting on the leverage ratio $[\ldots]$ and in order to enable the competent authorities to monitor leverage ratio volatility, in particular around reporting reference dates, large institutions shall report specific components of the leverage ratio to their competent authorities, based on averages over the reporting period and the data used to calculate those averages'. The European Banking Authority shall set the implementing technical standards, specifying which components of the leverage ratio shall be reported using day-end or month-end values.
} 


\section{The euro repo market: some stylized facts}

After the outbreak of the global financial crisis, and owing to heightened risk aversion in the financial system, the repo market gained importance as interbank transactions moved from the unsecured to the secured segment. In more recent years, repo market turnover has continued to grow, as shown by the increase in the turnover of the RepoFunds Rate indices (Figure 1), ${ }^{10}$ amid lower risk aversion compared with the early years of the global financial crisis and the euro-area sovereign debt crisis. The latest ICMA European repo market surveys confirm the growth of this market segment: the aggregate value of outstanding repos and reverse repos grew by 19.4 per cent year-on-year in 2017 and by 5.9 per cent in 2018 (ICMA, 2018 and 2019). ${ }^{11}$ In an environment featuring ample excess liquidity, driven by the Eurosystem's non-standard monetary policy measures, repo rates based on collateral from many euroarea jurisdictions trade persistently below the ECB deposit facility rate and show downward spikes at specific reporting dates, especially at year-end. In these occasions, a drop in repo market turnover can also be observed. Tensions in repo rates at reporting dates diminished in the course of 2018.

We examine the structure and the developments of the euro-area repo market by using data collected within the framework of the ECB euro Money Market Statistical Reporting (MMSR) Regulation. Since July 2016, the MMSR process collects daily data on euro-denominated transactions made by the 50 largest credit institutions in the euro area in four money market segments: unsecured, secured, OIS and FX swap. ${ }^{12}$ For each individual transaction, the dataset records the reporting agent's name, the tenor, the ISIN code of the underlying security, the rate and the counterparty. ${ }^{13}$

Repo transactions in the euro area are heavily concentrated in short-term maturities. On average, almost 90 per cent of repo transactions are traded on a one-day maturity (overnight, or ON; tom-next, or TN; and spot-next, or $\mathrm{SN}$ ). In terms of the type of collateral, more than 80 per cent is represented by sovereign bonds (bonds issued by financial corporations are around 14 per cent) and it is concentrated in the largest jurisdictions, such as Germany, Italy, France and Spain, which together cover more than 80 per cent of

\footnotetext{
${ }^{10}$ RepoFunds Rate (RFR) is a series of daily euro repo indices comprising RFR Euro, RFR Germany, RFR France, RFR Italy, RFR Spain, RFR Netherlands and RFR Belgium. The indices are calculated from trades executed on either the BrokerTec or the MTS electronic platform. All eligible repo trades are centrally cleared and RepoFunds Rate is calculated and published by NEX Data. For further details see: http://www.repofundsrate.com/

${ }^{11}$ The increase in the turnover in the repo market is more likely to be driven by the search for specific securities rather than by the need for collateralized funding (BIS, 2019). As highlighted in ECB (2018), the increased demand for high quality liquid assets (HQLA) and the scarcity effect induced by the ECB APP might have contributed to this development. The ICMA survey conducted in June 2019 and published in November 2019 shows a fall in the aggregate value of outstanding repos of 1.2 per cent since the December 2018.

12 For further references, see the ECB website on https://www.ecb.europa.eu/stats/financial_markets_and_interest_rates/money_market/html/index.en.html.

${ }^{13}$ If the counterparty belongs to the financial sector, its Legal Entity Identifier (LEI) must be reported. If the transaction is CCP-cleared, the reported counterparty of the transaction is the CCP and no information is provided on the actual entity that matches the trade. If the counterparty of the trade does not belong to the financial sector, the reporting agent is only required to report the economic sector of the counterparty and its country of residence. Therefore, non-bank financial counterparties cannot be identified in the MMSR database.
} 
the total repo turnover based on government bonds (Table 1). This set of transactions makes up our main data sample. When comparing it with the information contained in the ICMA survey on the European repo market conducted in December 2018, it turns out that our data represent more than 60 per cent of the total outstanding one-day repo turnover based on sovereign collateral issued by Italy, Germany, Spain, France, Belgium and the Netherlands. In terms of counterparties, most of the repo transactions are cleared through a CCP (around 60 per cent in Q4 2016, which increased to 75 per cent in Q4 2018), ${ }^{14}$, while bilateral interbank transactions are only a small percentage (around 10 per cent) of total repo turnover based on government securities. ${ }^{15}$ When looking at the geographical location of the MMSR reporting banks, it turns out that the role of non-bank financial institutions is significant in Spain, Germany, France and the Netherlands. In these countries, between 15 to 23 per cent of repo activity was conducted with non-bank entities in Q4 2018. In other countries, such as Italy, the role of non-bank entities is rather limited. ${ }^{16}$

The evidence from MMSR on repo rates and turnover confirms the evidence of the RepoFunds Rate indices. Repo turnover shows an upward trend since the beginning of the sample period, in July 2016, with some downward spikes at reporting dates, in particular at year-end (Figure 2). Repo rates based on government bond collateral also drop at reporting dates, especially at year-end. Market reports point to the leverage ratio as a key factor behind the volatility of money market rates at quarter-end. ${ }^{17}$

We seek to identify the features of the window-dressing carried out by banks at LR reporting dates in terms of volume and rates and the extent to which it can affect the overall repo market functioning. All MMSR reporting banks are incorporated in the euro area, so they are subject to the same LR framework as mandated by the EU Regulation. The balance sheet characteristics of the 50 MMSR reporting banks are summarized in Table 2 .

We examine the repo transaction data on the cash borrowing side of reporting banks for the following reasons. First, the cash borrowing side is of interest from the LR perspective. As pointed out in the

\footnotetext{
${ }^{14}$ The rising share of CCP cleared transactions has mainly been driven by an absolute increase in the total turnover of CCP cleared repo transactions.

${ }^{15}$ The MMSR dataset does not provide information on the actual counterparties behind CCP-cleared trades. Nevertheless, according to CCP membership lists, most clearing members are indeed banks, as also reported in some market commentaries.

${ }^{16}$ Within the non-bank financial category, repo activity is mainly conducted with non-money market investment funds and other financial intermediaries, while money market funds, insurance corporation and pension funds play a minor role.

${ }^{17}$ Market commentaries suggest that at reporting dates, some investors increase their turnover in the securities lending market at the expense of repo market activity. Securities lending encompasses (i) the loans of specific securities (usually trading at 'special repo' rates) against other generic securities (trading at the 'general repo' rate) and (ii) collateral swaps, whereby non-HQLA assets are exchanged for HQLA assets. These activities are balance sheet efficient since they do not consume balance sheet space, as cash is not transferred from one investor to another (ISLA, 2019). These transactions are captured neither by RepoFunds Rate data nor by MMSR data, so they fall outside the scope of this study. In comparison with repo market volume, the securities lending volume in Europe is lower and equivalent to 15 per cent of the former (ICMA, 2019).
} 
previous section, if a bank borrows cash in the repo market, the collateral pledged in the operation stays in the balance sheet of the bank and the cash received increases the size of the bank's asset side. Second, we are particularly interested in the pricing conditions that banks apply to non-bank financial institutions when the latter want to deposit secured funds with the banking sector. Indeed, repo transactions with the non-banking sector are not likely to be netted in the calculation of the exposure measure, since non-bank financial institutions are generally cash lenders in the current ample excess liquidity environment.

The euro repo market is segmented across collateral jurisdictions (BIS, 2019). At quarter-end, rate dispersion tends to widen for reasons relating to perceived collateral quality and specialness. Since we are mainly interested in identifying the effect of the LR across jurisdictions, we do not perform a country level analysis. However, owing to the granularity of our dataset, we can control for collateral-related factors such as country, bond quality, scarcity and specialness, as we will show later on.

In order to shed some light on the extent of banks' window-dressing, we start by comparing average repo rates and volume on one-day tenors computed throughout the sample with average repo rates and volume computed only at quarter-end. Volume (both absolute and relative to total assets) significantly declines only for transactions with non-banks, while CCP-cleared and interbank transactions do not drop at reporting dates (Table 3). Conversely, repo rates generally fall at quarter-end. One-day rates with nonbanks decline on average by 49 basis points, rates on CCP-cleared transactions decline by 74 basis points, and bilateral interbank rates decline by 17 basis points. The magnitude of the fall in rates at quarter-end has decreased over time for all kinds of counterparties (Figures 3-5). We interpret the latter phenomenon mainly as a consequence of the overall increase in LR levels over the sample period that has relieved peer pressure on banks and lessened the balance sheet cost of LR fulfilment.

In order to assess whether the LR affects the compensation that banks require to trade in the repo market at quarter-end, we look more closely into the rate differential between CCP-cleared and non-CCPcleared trades. This is a measure of the remuneration for the balance sheet cost that banks bear when a repo transaction cannot be netted (i.e. it is not conducted with the same $\mathrm{CCP}$ ). In order to measure this rate differential in isolation from other factors (individual bank characteristics, specific features of the underlying security, and so on), we collect a set of repo transactions where a specific security on a certain date is traded by a reporting bank both with CCP intermediation and bilaterally (with a non-bank or in the interbank market). We find that the repo rate differential between CCP-cleared and non-bank trades is equal to 6 basis points on average and increases to 19 basis points at quarter-end (Table 4). We interpret this rate differential mainly as the result of the market power of the banking system towards non-bank financial entities in the current excess liquidity environment. The institutional set-up of the euro area only grants access to the central bank balance sheet to direct monetary policy counterparties, i.e. banks. Non-bank intermediaries, which quite often are the ultimate sellers of securities within the APP, have piled up large amounts of liquidity that is not immediately reinvested but is placed with the banking system either in secured transactions or as deposits. In this institutional setting, banks can apply 
lower (more negative) rates to non-banks when balance sheet constraints become more binding (i.e. at quarter-end). Indeed, when comparing CCP transactions with bilateral interbank transactions, we see that rates are in line on average, even though interbank transactions are as costly as transactions with non-banks from a balance sheet point of view. Moreover, at quarter-end, the rate differential between interbank transactions and CCP-cleared transactions does not change.

\section{Econometric analysis}

The previous section described some regularities at quarter-end that could be due to the window-dressing behaviour of banks for LR purposes. However, a number of concomitant factors also come into play and may affect participation in the repo market, making it difficult to draw conclusions on the role of the LR of reporting banks if we simply considers univariate analysis. The aim of this section is to take a further step, by estimating LR-related effects in isolation from potentially confounding factors, also in order to gain potential insights into future market developments.

\subsection{Repo rates and volume on reporting dates}

We examine more closely the reasons why banks adjust one-day volume and rates at quarter-end using the following model:

(1) $\operatorname{Var}_{\text {ist }}=\beta_{0}+\beta_{1}$ Qend $_{t}+\beta_{2}$ Qend $_{t} \cdot L R_{i t}+\delta_{1}$ Yend $_{t}+\delta_{2}$ Qend $_{t} \cdot \operatorname{Ctrl}_{i t}+\delta_{3} \operatorname{Ctrl}_{i t}+$

$$
\delta_{4} \text { Country }_{i}+\alpha_{i}+t n_{s}+\varepsilon_{i s t}
$$

where: $\operatorname{Var}_{i s t}$ is either repo rate or volume (divided by total assets) traded by bank $i$ with tenor $s$ (ON, $\mathrm{TN}$ or $\mathrm{SN}$ ) on day $t ; \alpha_{i}$ are bank fixed effects; $t n_{s}$ are tenor fixed effects; $Q e n d_{t}$ is the dummy variable that indicates quarter-end; $L R_{i t}$ is the level of leverage ratio; Yend ${ }_{t}$ is the year-end dummy controlling for year-end additional effects; $\operatorname{Ctrl}_{i t}$ are bank-specific control variables; and Country $_{i}$ are dummy variables that control for the jurisdiction of the borrowing bank. A trade takes a Qend (Yend) unit value if it is open (i.e. it may contribute to the bank's exposure) on the last trading day of each quarter (year). The sample for this analysis includes banks that carried out transactions via a CCP, with non-bank entities or in the bilateral interbank market in at least half of the trading days within the reference period. We run a fixed-effects panel estimation with clustered standard errors at security level and, separately, random effects estimates to capture not only the impact of a change in the leverage ratio level of individual banks, but also the effect of the leverage ratio on the degree of window-dressing. Hausman tests are run to check whether the use of random effects is possible.

At quarter-end, a significant decline in repo rates is observed for transactions with non-banks (of 16 basis points; Table 5) and CCPs (17 basis points; Table 6). Moderately significant results are obtained 
for interbank transactions, but their magnitude is less material ( 6 basis points; Table 7). At year-end, the fall in repo rates intensifies as transactions with non-banks involve a further 1.36 per cent drop in the rate while CCP-cleared transactions involve a further 2.05 per cent drop. The decline in repo rates depends on the banks' individual LR level only for transactions conducted with non-banks. The interaction coefficient between $Q$-end and $L R$ (equal to 0.24 ) implies that a bank whose leverage ratio is one percentage point below (above) the average sample level reduces (raises) the repo rate at quarterend by a further 24 basis points when the counterparty is a non-bank financial entity compared with a bank whose LR equals the sample average. This confirms the evidence in the previous section, suggesting that banks - especially those with a low LR - exert their market power at quarter-end as ratesetters to non-banks.

As regards volume, a modest decline at quarter-end is only observed for transactions conducted with non-banks (by 0.04 per cent of the balance sheet size, or 5 per cent of the average one-day activity with non-banks; Table 5) and for interbank bilateral trades (by 0.01 per cent of the balance sheet size or 1.5 per cent of one-day interbank activity; Table 7). No significant effect related to the LR level is observed.

\subsection{CCP-cleared transactions vs other transactions}

Next, we examine the rate differential between CCP-cleared and non-CCP cleared transactions to assess the compensation required by banks to borrow in the repo market from counterparties that generally do not benefit from the netting of exposures, resulting in an LR-related balance sheet cost. The rate differential between CCP-cleared trades and non-CCP-cleared trades is measured by only taking into account transactions conducted by a reporting bank with both CCPs and non-banks (or in the bilateral interbank market) on the same date, with the same tenor and the same underlying collateral, in line with section 3. We estimate the developments of rate differentials at quarter-end using the following model:

(2) RateDiff $_{\text {ijst }}=\beta_{0}+\beta_{1}$ Qend $_{t}+\beta_{2}$ Qend $_{t} \cdot L R_{i t}+\delta_{1}$ Yend $_{t}+\delta_{2}$ Qend $_{t} \cdot$ Ctrl $_{i t}+$

$$
\delta_{3} \text { Ctrl }_{i t}+\delta_{4} \text { Country }_{i}+\alpha_{i j s}+\varepsilon_{i j s t}
$$

where RateDiff $f_{i j s t}$ is the difference between the CCP-cleared rate and the non-CCP cleared rate applied by bank $i$ on day $t$ backed by security $j$ with tenor $s(\mathrm{ON}, \mathrm{TN}$ or $\mathrm{SN}) ; \alpha_{i j s}$ are bank-securitytenor fixed effects and all the other variables are as in equation (1).

We find that the rate differential between CCP-cleared and non-CCP cleared transactions does not change substantially at quarter-end, nor does the quarter-end effect depend on the level of the leverage ratio (Tables 8-9). This evidence suggests that quarter-end rate developments reported in section 3 for non-bank intermediaries (see Tables 3 and 4) may also be due to concomitant factors, different from the LR. 


\subsection{Bid-ask spread}

The bid-ask spread is another measure of the compensation that banks may require to trade in the repo market. Repo quotes are not available in the MMSR dataset, and the difference between rates on roundtrip trades is the closest we can get to the 'true' bid-ask spread of reporting banks. We thus compare the rate at which a bank borrows a specific security in the repo market and the rate at which it lends the same security on the same day.

The following model estimates the determinants of the bid-ask spread measured on round-trip transactions (borrowing and lending the same security on the same day with any economic agent or, alternatively, with CCPs only):

$$
\begin{gathered}
\text { (3) } \text { BidAsk }_{i t}=\beta_{1} \text { Qend }_{t}+\beta_{2} \text { Qend }_{t} \cdot \text { LR }_{i t}+\delta_{1} \text { Yend }_{t}+\theta_{1} w_{i t}^{N B}+\theta_{2} w_{i t}^{B I L}+\theta_{3} w_{i t}^{S R}+\delta_{2} \text { Ctrl }_{i t}+ \\
+\delta_{3} \text { Ctrl }_{i t} \cdot \text { Qend }_{t}+\delta_{4} \text { Country }_{i}+\alpha_{i}+\gamma_{t}+\varepsilon_{i t}
\end{gathered}
$$

where BidAsk $k_{i t}$ is the weighted average daily bid-ask spread applied by bank $i$ on day $t ; w_{i t}^{N B}\left(w_{i t}^{B I L}\right)$ is the share of the volume transacted with non-bank financial entities (or bilaterally with other banks) over the total volume of borrowing transactions by bank $i$ on day $t$. Hence $\theta_{1}$ and $\theta_{2}$ can be interpreted as the amount of additional compensation that a bank requires to enter a round-trip trade with borrowing entities which do not clear via a CCP; $w_{i t}^{S R}$ is the share of special repo volume over total repo volume; ${ }^{18}$ all other variables are as in equation (1).

The sample is made up of transactions in which for the same reporting bank, the same underlying security, on the same day borrowing and lending volumes are very similar, ${ }^{19}$ i.e. the reporting bank is on both sides of the market on that day. The difference between the lending rate and the borrowing rate is then averaged (weighted by the transaction volume) at bank-date level in order to get the daily average bid-ask spread.

We find that the bid-ask spread does not significantly change at quarter-end, while it widens at year-end by about 30 basis points (Table 10). Moreover, the level of leverage ratio does not affect the changes in this measure of compensation at reporting dates. On average, the share of trades conducted with nonbanks affects the size of the bid-ask spread. If a bank borrows entirely from non-bank entities $\left(w_{i t}^{N B}=\right.$ 100 ), the bid-ask spread is around 5.5 basis points higher than the average. This figure is comparable to

\footnotetext{
${ }^{18}$ For our purposes, special repo transactions are defined as follows. The repo rate of each ISIN is computed for each day. Those transactions whose rates are below the median rate of the collateral jurisdiction on each day are labelled as 'special'. In the sample period, special repo transactions represent more than 50 per cent of transactions conducted in the repo market for all major European jurisdictions. This selection criterion is quite conservative as it identifies half of the securities traded each day in each jurisdiction, and some special repo transactions are therefore left out using this criterion.

$19 \frac{\mid \text { BorrVolume-LendVolume } \mid}{\text { BorrVolume }+ \text { LendVolume }}<5 \%$.
} 
the average rate differential between CCP-cleared transactions and transactions with non-banks derived in section 3. As for fully CCP-cleared round-trip trades (that have no balance sheet cost from a leverage ratio perspective), we document no significant quarter-end effect, as expected, but a more pronounced year-end effect (the bid-ask spread increases by about 60 basis points; Table 11). The year-end effect, also for wholly CCP-cleared transactions, supports the idea that on these dates, factors different from the LR play a key role in the estimated increase of the compensation required by banks to trade in the repo market. As already pointed out, the G-SIB score assessment, tax levies as well as other contributions linked to the size of the balance sheet may incentivize banks to reduce their repo business ahead of the publication of the annual statement. ${ }^{20}$

Looking ahead, the evidence presented in this section suggests that in the near future, when average LR exposures will also have to be reported, banks will not necessarily widen the bid-ask spread as a compensation for their repo activity.

\subsection{Net repo exposure}

In this section, we analyse the contribution of repo activity to banks' LR exposure and its changes around reporting dates. To this end, we compute each bank's individual exposure after netting repo positions with the same counterparty (generally a CCP) and the same final settlement date. We call this variable 'net repo exposure' or 'net exposure' for brevity. A decline in gross repo exposure can be observed for different counterparty types at quarter end; the decline seems more pronounced for CCP-cleared transactions and if measured on a net basis, is consistent with window-dressing for LR-purposes (Figure $6)$.

The following model measures the changes in net exposure at quarter-end:

$$
\begin{gathered}
S_{i t}=\beta_{0}+\alpha_{i}+\beta_{1} \text { Qend }_{t}+\beta_{2} \text { Qend }_{t} \cdot L R_{i t}+\delta_{1} \text { Yend }_{t}+\delta_{2} \text { Qend }_{t} \cdot \text { Ctrl }_{i t}+\delta_{3} \text { Ctrl }_{i t}+ \\
\delta_{4} \text { Country }_{i}+\varepsilon_{i t}
\end{gathered}
$$

where $S_{i t}$ is the net repo exposure alternatively with non-banks, CCPs and other banks in the interbank market on any maturity by bank $i$ on day $t$; all other variables are as in the previous regression models.

We run three separate regressions for each counterparty type. In the case of non-banks, we find only a mildly significant drop in net exposure at quarter-end in the last specification (Table 12). The net exposure towards CCPs shows a highly significant drop at quarter-end by 0.32 per cent of banks' total assets (or 15 per cent of net exposure with CCPs; Table 13); the extent of this decline is only mildly related to the leverage ratio in the last regression; no further decline is observed at year-end. Net

\footnotetext{
${ }^{20}$ Behn et al. (2019) highlight the key role of the G-SIB framework compared with other factors such as contributions to the Single Resolution Fund or bank levies.
} 
exposure in the bilateral interbank market declines by 0.1 per cent of banks' total assets at quarter-end (Table 14), but the result is only significant at the 10 per cent confidence level.

These results show that banks reduce their net repo exposure at quarter-end especially with CCPs, possibly in order to improve their LR measure, and this adjustment is mildly related to the level of LR. In a forward-looking perspective, these developments suggest two possible actions by banks under LR average reporting: (i) a reduction in absolute terms of the repo activity that cannot be netted; and (ii) a shift of repo business towards counterparties, notably CCPs, which easily lend themselves to exposure netting. While the two behaviours may be complementary, the evidence above indicates that the latter might be prominent.

\section{Conclusions}

The leverage ratio framework proposed by the BCBS in 2010 introduced a capital cost on repo transactions, which had been practically exempted under traditional risk-weighted capital requirements. This has produced adjustments in repo activity and triggered some concerns, also in light of the role of the repo market for the transmission of monetary policy. In this paper, we measure as accurately as possible the LR effect on repo market activity in the euro area around quarter-end, when the LR is strictly binding (i.e. it must be reported and disclosed) according to the current European legislation.

After controlling for several factors that may affect participation in the repo market, banks are found to exert their market power over non-bank financial institutions by applying lower rates and larger bid-ask spreads. Interestingly, while there is a permanent rate differential between transactions conducted via central counterparties, which are likely to be netted for LR purposes, and transactions conducted with non-banks, at quarter-end this differential is unaffected by the LR level of the reporting bank. Similarly, after controlling for concomitant factors, the bid-ask spread is not affected by the LR on the same dates. These two findings suggest that the leverage ratio may not play a major role in this respect. Conversely at year-end, the widening of the bid-ask spread is sizeable, but this is not necessarily the result of the LR, since other factors relating to the size of the banks' balance sheet enter into play. At quarter-end, we observe significant drops in net repo exposure via CCPs, i.e. the amount that is left over after the netting of positions that settle on the same date, which seems linked to LR-motivated window-dressing. In light of the recent regulatory change in the euro area, which will require large banks to disclose their LR also based on quarterly averages as of June 2021, these findings can provide some insights into the possible evolution of the repo market. It seems likely that repo market participants will continue to make increasing recourse, in absolute and relative terms, to business with central counterparties and that CCPclearing services will keep on improving. The evidence in this paper does not seem to support the concern that repo market activity might suffer from a significant contraction in repo volumes, while rates would become more dispersed and possibly shift downwards. In turn, this lessens the concern over 
the possible impairment of the repo market as a key transmission channel for monetary policy in the euro area following the implementation of stricter leverage rules. 


\section{FIGURES AND TABLES}

Figure 1: RepoFunds rates (\%, LHS panel) and volume (billions of euros, RHS panel)
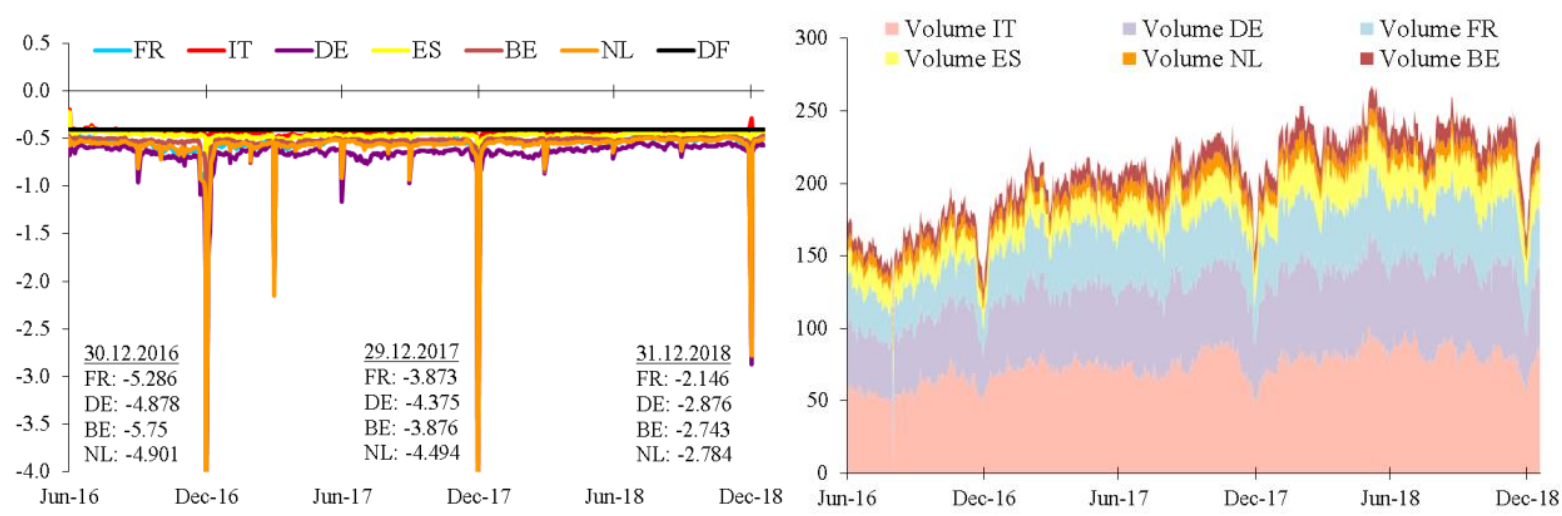

Source: RepoFunds Rates

Figure 2: Repo rates (LHS panel) and volumes (RHS panel) (\% and billions of euros)

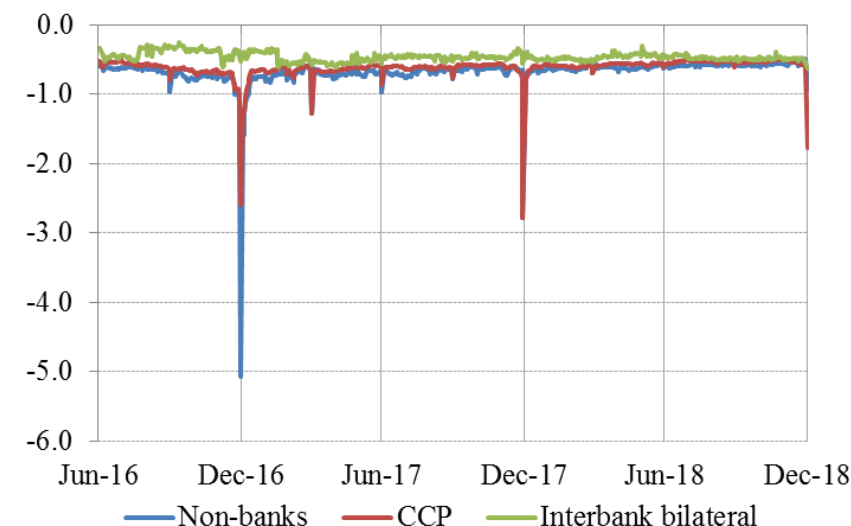

-Non-banks —CCP Interbank bilateral

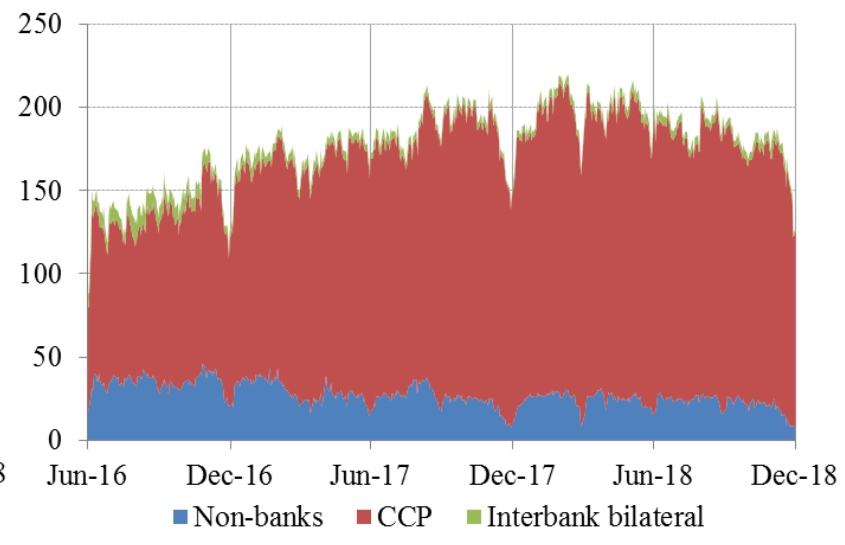

Source: MMSR.

Note: Sample transactions are cash borrowing transactions by MMSR reporting agents on ON, TN, SN tenors with collateral issued by BE, DE, ES, FR, IT, NL governments reported by settlement date. The non-banks category includes financial and non-financial corporations except for households and governments. 
Figure 3: Repo rates (LHS panel) and volume (RHS panel) with non-banks (\% and billions of euros)
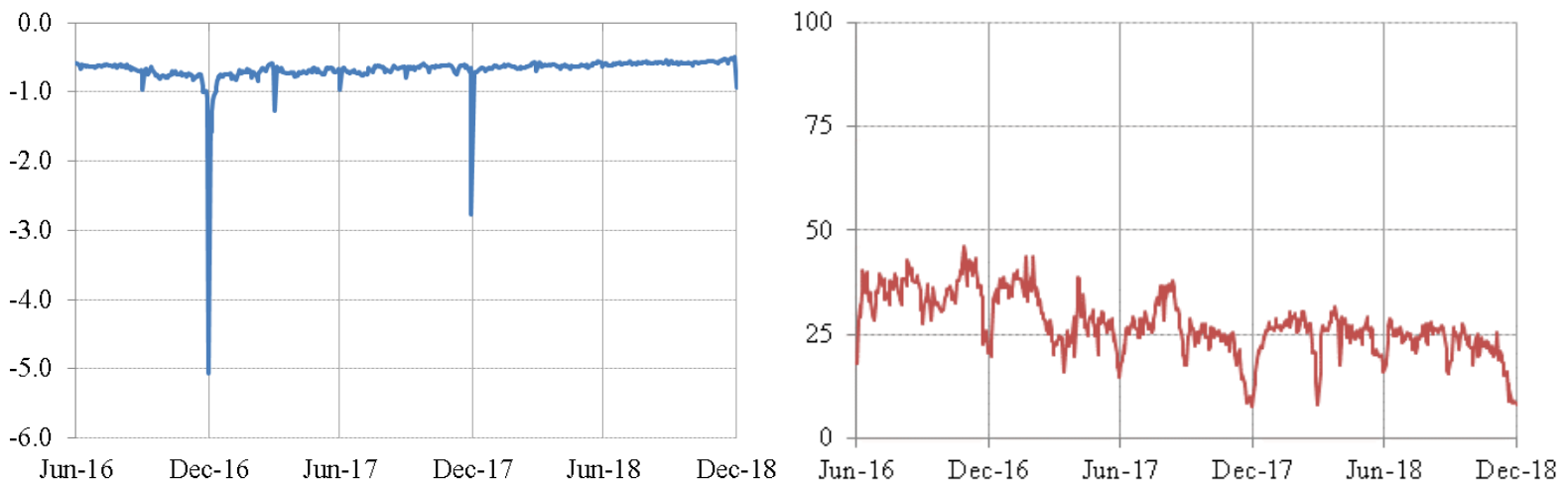

Source: MMSR.

Note: Sample transactions are cash borrowing transactions by MMSR reporting agents on ON, TN, SN tenors with collateral issued by BE, DE, ES, FR, IT, NL governments reported by settlement date. Counterparties include financial and non-financial corporations except for households and governments.

Figure 4: Repo rates (LHS panel) and volume (RHS panel) with CCPs (\% and billions of euros)
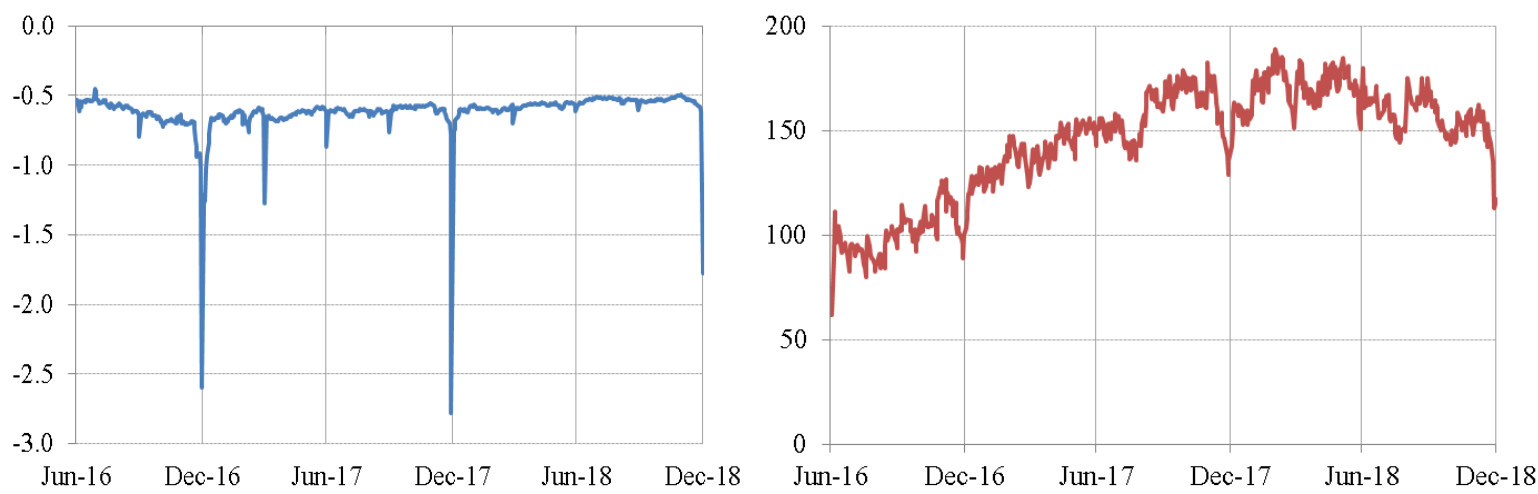

Source: MMSR.

Note: Sample transactions are CCP-cleared cash borrowing transactions by MMSR reporting agents on ON, TN, SN tenors with collateral issued by BE, DE, ES, FR, IT, NL governments reported by settlement date.

Figure 5: Repo rates (LHS panel) and volume (RHS panel) with other banks (\% and billions of euros)
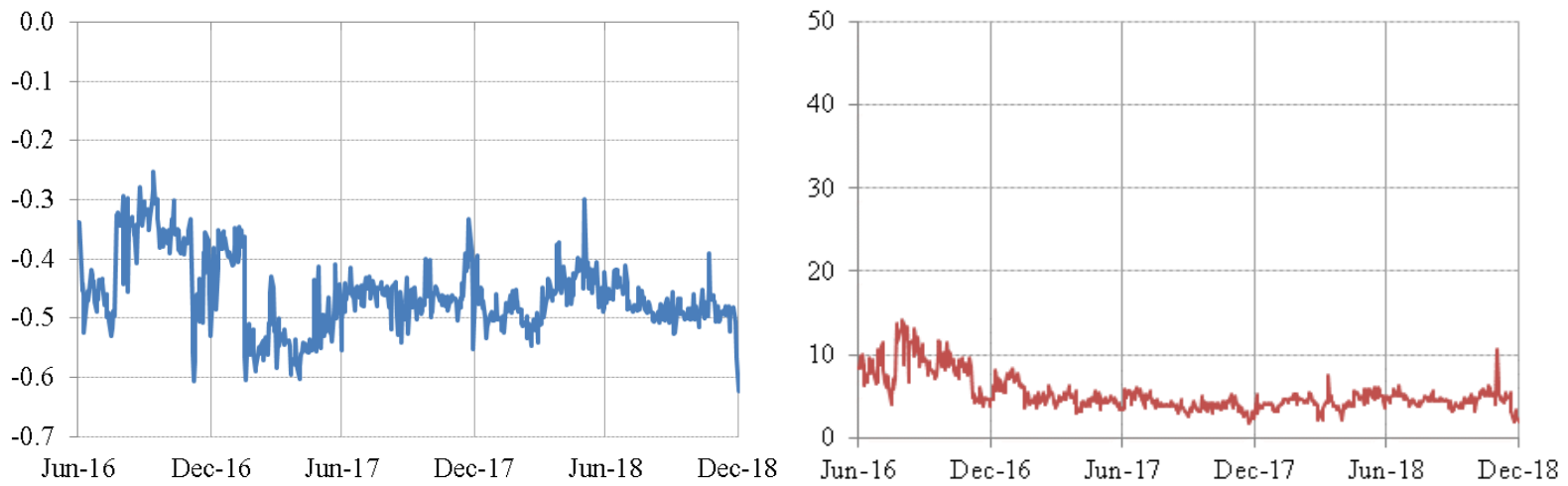

Source: MMSR.

Note: Sample transactions are non-CCP cleared cash borrowing transactions by MMSR reporting agents on ON, TN, SN tenors with collateral issued by BE, DE, ES, FR, IT, NL governments involving two banks reported by settlement date. 
Figure 6: Net repo exposure by counterparty (billions of euros)

\section{Non-bank intermediaries}

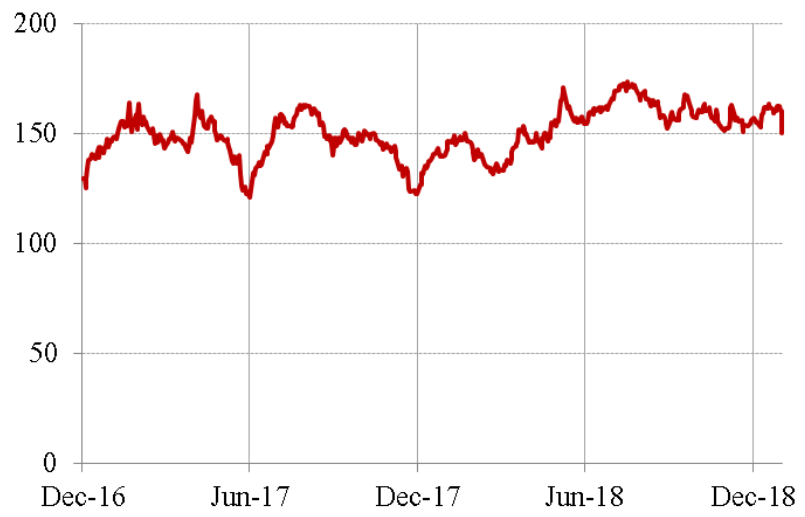

\section{Bilateral interbank}

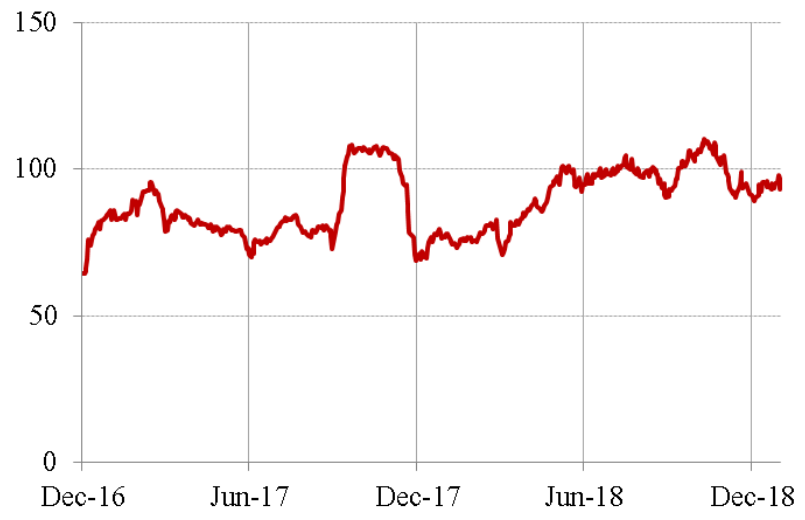

\section{CCPs gross (dark-red line) and net borrowing (light-red line)}

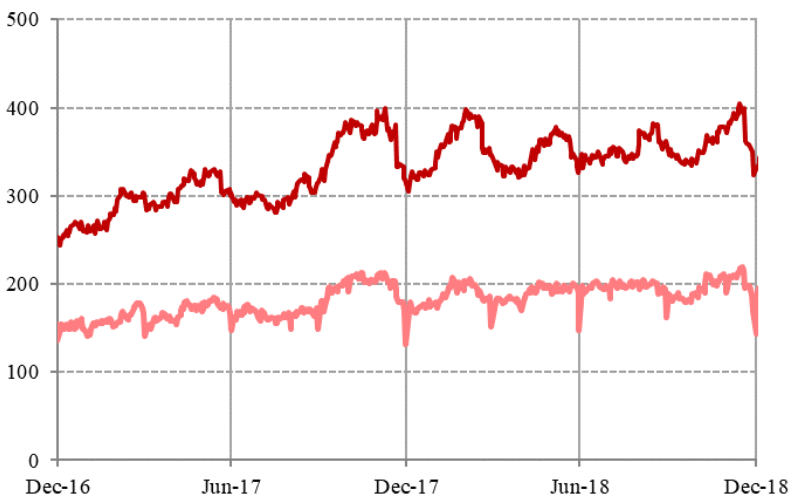

Source: MMSR.

Notes: Sample transactions are cash borrowing transactions by MMSR reporting agents on all tenors with collateral issued by BE, DE, ES, FR, IT, NL governments. Net repo exposure is computed by summing all transactions settled from 1 July 2016 to the reported date and maturing after the reported date. Charts start on 31 December 2016 instead of 1 July 2016 because we need a sufficiently long time series of transaction data to derive a reliable measure of outstanding volume. CCP net borrowing is computed by subtracting transactions with a matching maturity date and a matching counterparty on the cash lending and cash borrowing side from the outstanding repo borrowing. 
Table 1: Repo activity breakdown by collateral jurisdiction - (Repo/cash borrowing turnover - \%)

\begin{tabular}{lcccccccc|c}
\hline & $B E$ & $D E$ & $E S$ & $I T$ & $F R$ & NL & $\begin{array}{c}\text { Other euro } \\
\text { area }\end{array}$ & Non-euro area & Total \\
\hline Q4 2016 & 7 & 30 & 9 & 22 & 17 & 6 & 6 & 3 & 100 \\
Q4 2018 & 6 & 27 & 12 & 24 & 17 & 5 & 6 & 2 & 100
\end{tabular}

Source: MMSR.

Note: Sample transactions are cash borrowing transactions by MMSR reporting agents on ON, TN, SN tenors with collateral issued by BE, DE, ES, FR, IT, NL governments.

Table 2: Balance sheet variables (December 2017)

\begin{tabular}{lrrrrr}
\hline & $N$ & Mean & Std. Dev. & \multicolumn{1}{c}{ Min } & \multicolumn{1}{c}{ Max } \\
\hline$L R$ & 31 & 4.8 & 0.9 & 3.3 & 6.8 \\
$\log ($ TA $)$ & 35 & 19.7 & 0.8 & 18.4 & 21.4 \\
$\log ($ repo $)$ & 40 & 7.5 & 1.9 & 2.3 & 10.0 \\
Tier 1 ratio & 32 & 15.1 & 2.0 & 12.7 & 21.1
\end{tabular}

Source: SNL Financials. 
Table 3: Daily volume and rates for one-day transactions

\begin{tabular}{lrrr}
\hline Non-banks & Average & \multicolumn{1}{c}{ Q-end } & Difference \\
\hline Volume (EUR mln) & 1,414 & 879 & $535(* * *)$ \\
Volume / TA (\%) & 0.21 & 0.14 & $0.08(* * *)$ \\
Rate (\%) & -0.61 & -1.10 & $0.49(* * *)$ \\
& & & \\
\hline CCP & Average & Q-end & Difference \\
\hline Volume (EUR mln) & 4,768 & 4,815 & -47 \\
Volume / TA (\%) & 1.38 & 1.41 & -0.03 \\
Rate (\%) & -0.61 & -1.35 & $0.74(* * *)$ \\
& & & \\
\hline Bilateral interbank & Average & -end & Difference \\
\hline Volume (EUR mln) & 245 & 195 & 50 \\
Volume / TA (\%) & 0.06 & 0.05 & 0.02 \\
Rate (\%) & -0.58 & -0.74 & $0.17(* * *)$
\end{tabular}

Source: MMSR.

Notes: Sample transactions are cash borrowing transactions by MMSR reporting agents on ON, TN, SN tenors with collateral issued by BE, DE, ES, FR, IT, NL governments. The non-banks category includes financial and non-financial corporations except for households and governments.

Table 4: Rate differential (\%)

\begin{tabular}{lrrr}
\hline Rate differential & Average & \multicolumn{1}{c}{ Q-end } & \multicolumn{1}{c}{ Difference } \\
\hline$C C P$ vs Non-banks & 0.06 & 0.19 & $0.13(* * *)$ \\
$C C P$ vs Bilateral interbank & 0.00 & -0.03 & -0.03
\end{tabular}

${ }^{*} p<0.1,{ }^{* *} p<0.05,{ }^{* * *} p<0.01$

Source: MMSR.

Notes: Sample transactions are cash borrowing transactions by MMSR reporting agents on ON, TN, SN tenors with collateral issued by BE, DE, ES, FR, IT, NL governments. Transactions are selected as those where a specific security on a certain date is traded by a reporting bank both with CCP intermediation and bilaterally (with a non-bank or in the interbank market). 
Table 5: Repo rates and volume - Non-bank counterparties

\begin{tabular}{|c|c|c|c|c|c|c|}
\hline & $\begin{array}{l}\text { (1) } \\
\text { Rate }\end{array}$ & $\begin{array}{l}\text { (2) } \\
\text { Rate }\end{array}$ & $\begin{array}{c}\text { (3) } \\
\text { Rate }\end{array}$ & $\begin{array}{c}\text { (4) } \\
\text { Volume / TA }\end{array}$ & $\begin{array}{c}(5) \\
\text { Volume / TA }\end{array}$ & $\begin{array}{c}(6) \\
\text { Volume /TA }\end{array}$ \\
\hline Q-end & $\begin{array}{c}-0.159 * * * \\
(0.0338)\end{array}$ & $\begin{array}{c}-0.164 \\
(0.969)\end{array}$ & $\begin{array}{l}-0.252 \\
(0.981)\end{array}$ & $\begin{array}{l}-0.0359 * \\
(0.0179)\end{array}$ & $\begin{array}{c}-0.451 * \\
(0.257)\end{array}$ & $\begin{array}{c}-0.406 \\
(0.256)\end{array}$ \\
\hline$Q$-end $* L R$ & & $\begin{array}{c}0.240 * * \\
(0.108)\end{array}$ & $\begin{array}{c}0.245 * * \\
(0.109)\end{array}$ & & $\begin{array}{l}0.00206 \\
(0.0160)\end{array}$ & $\begin{array}{c}-0.00118 \\
(0.0158)\end{array}$ \\
\hline$Y$-end & $\begin{array}{c}-1.360 * * * \\
(0.319)\end{array}$ & $\begin{array}{c}3.939 \\
(4.820)\end{array}$ & $\begin{array}{c}3.936 \\
(4.826)\end{array}$ & $\begin{array}{c}-0.0000265 \\
(0.0234)\end{array}$ & $\begin{array}{l}-0.257 \\
(0.222)\end{array}$ & $\begin{array}{l}-0.255 \\
(0.225)\end{array}$ \\
\hline Tenor FE & Yes & Yes & Yes & Yes & Yes & Yes \\
\hline$Q$-end controls & No & Yes & Yes & No & Yes & Yes \\
\hline$Y$-end controls & No & Yes & Yes & No & Yes & Yes \\
\hline Bank FE & Yes & No & Yes & Yes & No & Yes \\
\hline Country dummies & No & Yes & No & No & Yes & No \\
\hline Bank controls & No & Yes & No & No & Yes & No \\
\hline Constant & $\begin{array}{c}-0.616 * * * \\
(0.00987)\end{array}$ & $\begin{array}{l}0.0860 \\
(1.091)\end{array}$ & $\begin{array}{c}-0.620 * * * \\
(0.0106)\end{array}$ & $\begin{array}{c}0.105 * * * \\
(0.0151)\end{array}$ & $\begin{array}{l}0 \\
(.)\end{array}$ & $\begin{array}{c}0.104 * * * \\
(0.0153)\end{array}$ \\
\hline $\begin{array}{l}\mathrm{N} \\
\mathrm{R} 2\end{array}$ & $\begin{array}{c}20963 \\
0.161\end{array}$ & 19887 & $\begin{array}{l}19887 \\
0.189\end{array}$ & $\begin{array}{l}20106 \\
0.0524\end{array}$ & 19898 & $\begin{array}{c}19898 \\
0.0649\end{array}$ \\
\hline
\end{tabular}

Standard errors in parentheses

${ }^{*} p<0.1,{ }^{* *} p<0.05,{ }^{* * *} p<0.01$

Notes: $\operatorname{Var}_{i s t}=\beta_{0}+\beta_{1}$ Qend $_{t}+\beta_{2}$ Qend $_{t} \cdot L R_{i t}+\delta_{1}$ Yend $_{t}+\delta_{2}$ Qend $_{t} \cdot \operatorname{Ctrl}_{i t}+\delta_{3}$ Ctrl $_{i t}+\delta_{4}$ Country $_{i}+\alpha_{i}+$ tn $_{s}+$ $\varepsilon_{i s t} . \operatorname{Var}_{i s t}$ is either repo rate or volume (divided by total assets) traded by bank $i$ with tenor $s\left(\mathrm{ON}\right.$, TN or SN) on day $t ; \alpha_{i}$ are bank fixed effects; $t n_{s}$ are tenor fixed effects; Qend $_{t}$ is the dummy variable that indicates quarter-end; $L R_{i t}$ is the level of leverage ratio; Yend $t_{t}$ is the year-end dummy controlling for year-end additional effects; $C_{t r l} l_{i t}$ are bank-specific control

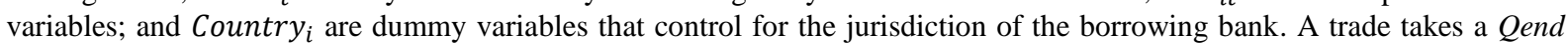
(Yend) unit value if it is open (i.e. it may contribute to the bank's exposure) on the last trading day of each quarter (year).

The sample for this analysis includes banks that carried out transactions with CCP at least in half of the trading days within the reference period. Hausman tests are run to check whether the use of random effects is possible. 
Table 6: Repo rates and volume - CCP-cleared

\begin{tabular}{|c|c|c|c|c|c|c|}
\hline & $\begin{array}{c}(1) \\
\text { Rate }\end{array}$ & $\begin{array}{c}(2) \\
\text { Rate }\end{array}$ & $\begin{array}{l}(3) \\
\text { Rate }\end{array}$ & $\begin{array}{c}(4) \\
\text { Volume /TA }\end{array}$ & $\begin{array}{c}\text { (5) } \\
\text { Volume / TA }\end{array}$ & $\begin{array}{c}\text { (6) } \\
\text { Volume / TA }\end{array}$ \\
\hline$Q$-end & $\begin{array}{c}-0.172 * * * \\
(0.0196)\end{array}$ & $\begin{array}{l}-0.511 \\
(0.583)\end{array}$ & $\begin{array}{l}-0.611 \\
(0.596)\end{array}$ & $\begin{array}{c}0.0241 \\
(0.0309)\end{array}$ & $\begin{array}{c}0.143 \\
(0.759)\end{array}$ & $\begin{array}{c}0.184 \\
(0.739)\end{array}$ \\
\hline$Q$-end $* L R$ & & $\begin{array}{l}0.0710 \\
(0.106)\end{array}$ & $\begin{array}{l}0.0760 \\
(0.106)\end{array}$ & & $\begin{array}{c}0.0153 \\
(0.0295)\end{array}$ & $\begin{array}{c}0.0162 \\
(0.0299)\end{array}$ \\
\hline$Y$-end & $\begin{array}{c}-2.046 * * * \\
(0.248)\end{array}$ & $\begin{array}{c}-9.693 * * \\
(3.981)\end{array}$ & $\begin{array}{c}-9.705 * * \\
(3.989)\end{array}$ & $\begin{array}{l}-0.0832 * \\
(0.0473)\end{array}$ & $\begin{array}{c}-1.763 * * \\
(0.732)\end{array}$ & $\begin{array}{c}-1.820 * * \\
(0.739)\end{array}$ \\
\hline Tenor FE & Yes & Yes & Yes & Yes & Yes & Yes \\
\hline$Q$-end controls & No & Yes & Yes & No & Yes & Yes \\
\hline$Y$-end controls & No & Yes & Yes & No & Yes & Yes \\
\hline Bank FE & Yes & No & Yes & Yes & No & Yes \\
\hline Country dummies & No & Yes & No & No & Yes & No \\
\hline Bank controls & No & Yes & No & No & Yes & No \\
\hline Constant & $\begin{array}{c}-0.535^{* * *} \\
(0.0198)\end{array}$ & $\begin{array}{l}-1.016^{*} \\
(0.572)\end{array}$ & $\begin{array}{c}-0.526 * * * \\
(0.0219)\end{array}$ & $\begin{array}{l}-0.0181 \\
(0.191)\end{array}$ & $\begin{array}{l}5.605^{* *} \\
(2.673)\end{array}$ & $\begin{array}{c}-0.000961 \\
(0.161)\end{array}$ \\
\hline $\begin{array}{l}\mathrm{N} \\
\mathrm{R} 2 \\
\text { Standard errors in pare } \\
{ }^{*} p<0.1,{ }^{* *} p<0.05,{ }^{* *}\end{array}$ & $\begin{array}{l}46381 \\
0.260\end{array}$ & 39970 & $\begin{array}{l}39970 \\
0.298\end{array}$ & $\begin{array}{l}45021 \\
0.242\end{array}$ & 40159 & $\begin{array}{l}40159 \\
0.247\end{array}$ \\
\hline \multicolumn{7}{|c|}{ 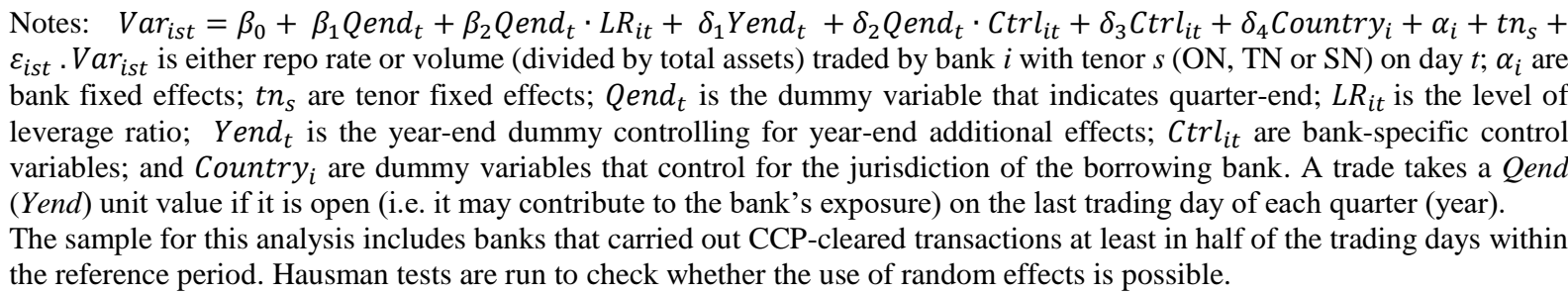 } \\
\hline
\end{tabular}


Table 7: Repo rates and volume - Interbank bilateral

\begin{tabular}{|c|c|c|c|c|c|c|}
\hline & $\begin{array}{c}\text { (1) } \\
\text { Rate }\end{array}$ & $\begin{array}{c}(2) \\
\text { Rate }\end{array}$ & $\begin{array}{c}\text { (3) } \\
\text { Rate }\end{array}$ & $\begin{array}{c}(4) \\
\text { Volume / TA }\end{array}$ & $\begin{array}{c}(5) \\
\text { Volume / TA }\end{array}$ & $\begin{array}{c}(6) \\
\text { Volume / TA }\end{array}$ \\
\hline Q-end & $\begin{array}{l}-0.0577 * \\
(0.0282)\end{array}$ & $\begin{array}{l}-0.190 \\
(0.523)\end{array}$ & $\begin{array}{l}-0.306 \\
(0.543)\end{array}$ & $\begin{array}{c}-0.00965^{*} \\
(0.00507)\end{array}$ & $\begin{array}{l}-0.132 * \\
(0.0790)\end{array}$ & $\begin{array}{c}-0.125 \\
(0.0800)\end{array}$ \\
\hline$Q$-end $* L R$ & & $\begin{array}{c}0.115 \\
(0.100)\end{array}$ & $\begin{array}{c}0.120 \\
(0.102)\end{array}$ & & $\begin{array}{l}-0.000882 \\
(0.00323)\end{array}$ & $\begin{array}{l}-0.00140 \\
(0.00340)\end{array}$ \\
\hline$Y$-end & $\begin{array}{l}-0.321 \\
(0.203)\end{array}$ & $\begin{array}{c}7.277 \\
(8.199)\end{array}$ & $\begin{array}{c}7.287 \\
(8.206)\end{array}$ & $\begin{array}{c}-0.000443 \\
(0.00676)\end{array}$ & $\begin{array}{l}0.272 * \\
(0.151)\end{array}$ & $\begin{array}{l}0.274 * \\
(0.152)\end{array}$ \\
\hline Tenor FE & Yes & Yes & Yes & Yes & Yes & Yes \\
\hline$Q$-end controls & No & Yes & Yes & No & Yes & Yes \\
\hline$Y$-end controls & No & Yes & Yes & No & Yes & Yes \\
\hline Bank FE & Yes & No & Yes & Yes & No & Yes \\
\hline Country dummies & No & Yes & No & No & Yes & No \\
\hline Bank controls & No & Yes & No & No & Yes & No \\
\hline Constant & $\begin{array}{c}-0.578 * * * \\
(0.0135)\end{array}$ & $\begin{array}{l}-0.329 \\
(1.144)\end{array}$ & $\begin{array}{c}-0.568 * * * \\
(0.0142)\end{array}$ & $\begin{array}{c}0.0557 * * * \\
(0.00866)\end{array}$ & $\begin{array}{l}-0.303 \\
(0.349)\end{array}$ & $\begin{array}{c}0.0530 * * * \\
(0.00863)\end{array}$ \\
\hline $\begin{array}{l}\mathrm{N} \\
\mathrm{R} 2\end{array}$ & $\begin{array}{r}19440 \\
0.0115\end{array}$ & 17217 & $\begin{array}{l}17217 \\
0.0241\end{array}$ & $\begin{array}{r}18469 \\
0.0201\end{array}$ & 17219 & $\begin{array}{r}17219 \\
0.0395\end{array}$ \\
\hline
\end{tabular}

Standard errors in parentheses

${ }^{*} p<0.1,{ }^{* *} p<0.05,{ }^{* * *} p<0.01$

Notes: $\operatorname{Var}_{i s t}=\beta_{0}+\beta_{1}$ Qend $_{t}+\beta_{2}$ Qend $_{t} \cdot L R_{i t}+\delta_{1}$ Yend $_{t}+\delta_{2}$ Qend $_{t} \cdot \operatorname{Ctrl}_{i t}+\delta_{3}$ Ctrl $_{i t}+\delta_{4} \operatorname{Country}_{i}+\alpha_{i}+$ tn $_{s}+$ $\varepsilon_{i s t} . \operatorname{Var}_{i s t}$ is either repo rate or volume (divided by total assets) traded by bank $i$ with tenor $s\left(\mathrm{ON}\right.$, TN or SN) on day $t ; \alpha_{i}$ are bank fixed effects; $t n_{s}$ are tenor fixed effects; $Q_{e n d}$ is the dummy variable that indicates quarter-end; $L R_{i t}$ is the level of leverage ratio; Yend $_{t}$ is the year-end dummy controlling for year-end additional effects; Ctrl $_{i t}$ are bank-specific control variables; and Country $_{i}$ are dummy variables that control for the jurisdiction of the borrowing bank. A trade takes a Qend (Yend) unit value if it is open (i.e. it may contribute to the bank's exposure) on the last trading day of each quarter (year).

The sample for this analysis includes banks that carried out transactions in the bilateral interbank market in at least half of the trading days within the reference period. Hausman tests are run to check whether the use of random effects is possible. 
Table 8: Rate differential between CCP-cleared trades and trades with non-banks

\begin{tabular}{|c|c|c|c|}
\hline & $\begin{array}{c}\text { (1) } \\
\text { Differential }\end{array}$ & $\begin{array}{c}(2) \\
\text { Differential }\end{array}$ & $\begin{array}{c}(3) \\
\text { Differential }\end{array}$ \\
\hline$Q$-end & $\begin{array}{l}-0.0145 \\
(0.0242)\end{array}$ & $\begin{array}{l}-1.071 \\
(0.941)\end{array}$ & $\begin{array}{l}-1.656 * \\
(1.004)\end{array}$ \\
\hline$Q$-end $* L R$ & & $\begin{array}{c}0.0102 \\
(0.0945)\end{array}$ & $\begin{array}{c}0.0416 \\
(0.0723)\end{array}$ \\
\hline$Y$-end & $\begin{array}{c}0.152 \\
(0.213)\end{array}$ & $\begin{array}{l}-7.546 \\
(5.890)\end{array}$ & $\begin{array}{l}-7.244 \\
(5.860)\end{array}$ \\
\hline$Q$-end controls & No & Yes & Yes \\
\hline$Y$-end controls & No & Yes & Yes \\
\hline Bank-ISIN-Tenor FE & Yes & No & Yes \\
\hline Country dummies & No & Yes & No \\
\hline Bank controls & No & Yes & No \\
\hline Constant & $\begin{array}{l}0.0769 * * * \\
(0.000404)\end{array}$ & $\begin{array}{l}0.0818 * * * \\
(0.000448)\end{array}$ & $\begin{array}{l}0.0606 \\
(0.207)\end{array}$ \\
\hline $\begin{array}{l}\mathrm{N} \\
\mathrm{R} 2\end{array}$ & $\begin{array}{c}25571 \\
0.000995\end{array}$ & $\begin{array}{l}23696 \\
0.0120\end{array}$ & 23696 \\
\hline
\end{tabular}

Notes: $\quad$ RateDiff $_{i j s t}=\beta_{0}+\beta_{1}$ Qend $_{t}+\beta_{2}$ Qend $_{t} \cdot$ LR $_{i t}+\delta_{1}$ Yend $_{t}+\delta_{2}$ Qend $_{t} \cdot$ Ctrl $_{i t}+\delta_{3}$ Ctrl $_{i t}+\delta_{4}$ Country $_{i}+$ $\alpha_{i j s}+\varepsilon_{i j s t}$. RateDiff $f_{i j s t}$ is the difference between the CCP-cleared rate and the non-CCP cleared rate (transacted with nonbank intermediaries) applied by bank $i$ on day $t$ backed by security $j$ with tenor $s\left(\mathrm{ON}\right.$, TN or SN); $\alpha_{i j s}$ are bank-security-tenor fixed effects, $Q e n d_{t}$ is the dummy variable that indicates quarter-end; $L R_{i t}$ is the level of leverage ratio; $Y e n d_{t}$ is the year-end dummy controlling for year-end additional effects; and Country $y_{i}$ are dummy variables that control for the jurisdiction of the borrowing bank. A trade takes a Qend (Yend) unit value if it is open (i.e. it may contribute to the bank's exposure) on the last trading day of each quarter (year). Hausman tests are run to check whether the use of random effects is possible. 
Table 9: Rate differential between CCP-cleared trades and interbank bilateral trades

\begin{tabular}{|c|c|c|c|}
\hline & $\begin{array}{c}\text { (1) } \\
\text { Differential }\end{array}$ & $\begin{array}{c}(2) \\
\text { Differential }\end{array}$ & $\begin{array}{c}(3) \\
\text { Differential }\end{array}$ \\
\hline$Q$-end & $\begin{array}{l}-0.00117 \\
(0.0154)\end{array}$ & $\begin{array}{c}0.455 \\
(1.097)\end{array}$ & $\begin{array}{l}-0.0206 \\
(1.123)\end{array}$ \\
\hline$Q$-end $* L R$ & & $\begin{array}{l}-0.0265 \\
(0.0271)\end{array}$ & $\begin{array}{l}-0.0215 \\
(0.0278)\end{array}$ \\
\hline$Y$-end & $\begin{array}{c}-0.00740 \\
(0.0258)\end{array}$ & $\begin{array}{c}-0.354 \\
(1.678)\end{array}$ & $\begin{array}{l}-0.719 \\
(1.698)\end{array}$ \\
\hline$Q$-end controls & No & Yes & Yes \\
\hline$Y$-end controls & No & Yes & Yes \\
\hline Bank-ISIN-Tenor FE & Yes & No & Yes \\
\hline Country dummies & No & Yes & No \\
\hline Bank controls & No & Yes & No \\
\hline Constant & $\begin{array}{l}0.0418 * * * \\
(0.000207)\end{array}$ & $\begin{array}{l}0.0411 * * * \\
(0.000155)\end{array}$ & $\begin{array}{c}0.826 * * * \\
(0.213)\end{array}$ \\
\hline $\begin{array}{l}\mathrm{N} \\
\mathrm{R} 2\end{array}$ & $\begin{array}{c}22883 \\
0.0000177\end{array}$ & $\begin{array}{l}20657 \\
0.0131\end{array}$ & 20657 \\
\hline
\end{tabular}

Notes: $\quad$ RateDiff $_{i j s t}=\beta_{0}+\beta_{1}$ Qend $_{t}+\beta_{2}$ Qend $_{t} \cdot$ LR $_{i t}+\delta_{1}$ Yend $_{t}+\delta_{2}$ Qend $_{t} \cdot$ Ctrl $_{i t}+\delta_{3}$ Ctrl $_{i t}+\delta_{4}$ Country $_{i}+$ $\alpha_{i j s}+\varepsilon_{i j s t}$. RateDiff $f_{i j s t}$ is the difference between the CCP-cleared rate and the non-CCP cleared rate (transacted in the interbank bilateral market) applied by bank $i$ on day $t$ backed by security $j$ with tenor $s\left(\mathrm{ON}, \mathrm{TN}\right.$ or SN); $\alpha_{i j s}$ are bank-securitytenor fixed effects, $Q e n d_{t}$ is the dummy variable that indicates quarter-end; $L R_{i t}$ is the level of leverage ratio; $Y_{\text {end }}$ is the year-end dummy controlling for year-end additional effects; and Country $y_{i}$ are dummy variables that control for the jurisdiction of the borrowing bank. A trade takes a Qend (Yend) unit value if it is open (i.e. it may contribute to the bank's exposure) on the last trading day of each quarter (year). Hausman tests are run to check whether the use of random effects is possible. 
Table 10: Bid-ask spread - All counterparties

\begin{tabular}{|c|c|c|c|c|}
\hline & $\begin{array}{c}\text { (1) } \\
\text { Daily bid-ask }\end{array}$ & $\begin{array}{c}(2) \\
\text { Daily bid-ask }\end{array}$ & $\begin{array}{c}\text { (3) } \\
\text { Daily bid-ask }\end{array}$ & $\begin{array}{c}\text { (4) } \\
\text { Daily bid-ask }\end{array}$ \\
\hline$Q$-end & $\begin{array}{c}0.0235 \\
(0.0199)\end{array}$ & $\begin{array}{c}0.0258 \\
(0.0181)\end{array}$ & $\begin{array}{c}0.124 \\
(0.903)\end{array}$ & $\begin{array}{c}0.210 \\
(0.911)\end{array}$ \\
\hline$Q$-end $* L R$ & & & $\begin{array}{l}-0.0827 \\
(0.0613)\end{array}$ & $\begin{array}{l}-0.0853 \\
(0.0612)\end{array}$ \\
\hline$Y$-end & $\begin{array}{l}0.328^{*} \\
(0.173)\end{array}$ & $\begin{array}{l}0.332^{*} \\
(0.174)\end{array}$ & $\begin{array}{c}20.50 \\
(13.93)\end{array}$ & $\begin{array}{c}20.51 \\
(13.97)\end{array}$ \\
\hline$w($ non-banks $)$ & & $\begin{array}{c}0.000559 * * * \\
(0.000163)\end{array}$ & $\begin{array}{c}0.000447 * * * \\
(0.000140)\end{array}$ & $\begin{array}{c}0.000459 * * * \\
(0.000147)\end{array}$ \\
\hline$w$ (bilateral) & & $\begin{array}{c}0.000220 \\
(0.000443)\end{array}$ & $\begin{array}{l}0.0000960 \\
(0.000429)\end{array}$ & $\begin{array}{c}0.000103 \\
(0.000436)\end{array}$ \\
\hline$w($ special $)$ & & $\begin{array}{l}-0.0000784 \\
(0.000122)\end{array}$ & $\begin{array}{l}-0.0000503 \\
(0.000118)\end{array}$ & $\begin{array}{l}-0.0000523 \\
(0.000118)\end{array}$ \\
\hline$O N-T N-S N$ dummy & Yes & Yes & Yes & Yes \\
\hline$Q$-end controls & No & No & Yes & Yes \\
\hline$Y$-end controls & No & No & Yes & Yes \\
\hline Bank FE & Yes & Yes & No & Yes \\
\hline Country dummies & No & No & Yes & No \\
\hline Bank controls & No & No & Yes & No \\
\hline Constant & $\begin{array}{c}0.0420 * * * \\
(0.0148)\end{array}$ & $\begin{array}{c}0.0207 \\
(0.0139)\end{array}$ & $\begin{array}{l}-0.461 \\
(0.354)\end{array}$ & $\begin{array}{l}0.0233^{*} \\
(0.0122)\end{array}$ \\
\hline $\begin{array}{l}\mathrm{N} \\
\mathrm{R} 2\end{array}$ & $\begin{array}{c}9912 \\
0.0154\end{array}$ & $\begin{array}{c}9912 \\
0.0221\end{array}$ & 8181 & $\begin{array}{c}8181 \\
0.0448\end{array}$ \\
\hline
\end{tabular}

Standard errors in parentheses

${ }^{*} p<0.1,{ }^{* *} p<0.05,{ }^{* * *} p<0.01$

Notes: $\quad$ BidAsk $_{i t}=\beta_{1}$ Qend $_{t}+\beta_{2}$ Qend $_{t} \cdot L R_{i t}+\delta_{1}$ Yend $_{t}+\theta_{1} w_{i t}^{N B}+\theta_{2} w_{i t}^{B I L}+\theta_{3} w_{i t}^{S R}+\delta_{2} C_{t r l} l_{i t}++\delta_{3} C_{t r l}$. Qend $_{t}+\delta_{4}$ Country $_{i}+\alpha_{i}+\gamma_{t}+\varepsilon_{i t}$. BidAsk $k_{i t}$ is the weighted average daily bid-ask spread applied by bank $i$ on day $t ; w_{i t}^{N B}$ $\left(w_{i t}^{B I L}\right)$ is the share of volume transacted with non-bank financial entities (bilaterally with other banks) over the total volume of borrowing transactions by bank $i$ on day $t ; w_{i t}^{S R}$ is the share of special repo volume over total repo volume; $Q e n d_{t}$ is the dummy variable that indicates quarter-end; $L R_{i t}$ is the level of leverage ratio; $Y_{e n d_{t}}$ is the year-end dummy controlling for year-end additional effects; Country $i$ are dummy variables that control for the jurisdiction of the borrowing bank. A trade takes a Qend (Yend) unit value if it is open (i.e. it may contribute to the bank's exposure) on the last trading day of each quarter (year). Hausman tests are run to check whether the use of random effects is possible. Special repo transactions are defined as follows: the repo rate of each ISIN is computed for each day. Those transactions whose rates are below the median rate of the collateral jurisdiction on each day are labelled as 'special'. The sample is made up of transactions in which for the same reporting bank, the same underlying security, on the same day, borrowing and lending volumes are very similar $\left(\frac{\mid \text { BorrVolume-LendVolume } \mid}{\text { BorrVolume }+ \text { LendVolume }}<\right.$ $5 \%$ ). The difference between the lending rate and the borrowing rate is then averaged (weighted by the transaction volume) at bank-date level in order to get the daily average bid-ask spread. 
Table 11: Bid-ask spread - CCPs only

\begin{tabular}{|c|c|c|c|c|}
\hline & $\begin{array}{c}\text { (1) } \\
\text { Daily bid-ask }\end{array}$ & $\begin{array}{c}\text { (2) } \\
\text { Daily bid-ask }\end{array}$ & $\begin{array}{c}\text { (3) } \\
\text { Daily bid-ask }\end{array}$ & $\begin{array}{c}\text { (4) } \\
\text { Daily bid-ask }\end{array}$ \\
\hline$Q$-end & $\begin{array}{l}0.00597 \\
(0.0137)\end{array}$ & $\begin{array}{l}0.00611 \\
(0.0136)\end{array}$ & $\begin{array}{c}0.664 \\
(1.176)\end{array}$ & $\begin{array}{c}0.715 \\
(1.177)\end{array}$ \\
\hline$Q$-end $* L R$ & & & $\begin{array}{l}-0.0872 \\
(0.0581)\end{array}$ & $\begin{array}{l}-0.0898 \\
(0.0577)\end{array}$ \\
\hline$Y$-end & $\begin{array}{c}0.586 * * \\
(0.251)\end{array}$ & $\begin{array}{c}0.586 * * \\
(0.251)\end{array}$ & $\begin{array}{c}9.377 \\
(18.44)\end{array}$ & $\begin{array}{c}9.357 \\
(18.43)\end{array}$ \\
\hline$w($ special $)$ & & $\begin{array}{c}0.0000423 \\
(0.0000637)\end{array}$ & $\begin{array}{c}0.0000482 \\
(0.0000748)\end{array}$ & $\begin{array}{c}0.0000467 \\
(0.0000746)\end{array}$ \\
\hline$O N-T N-S N$ dummy & Yes & Yes & Yes & Yes \\
\hline$Q$-end controls & No & No & Yes & Yes \\
\hline$Y$-end controls & No & No & Yes & Yes \\
\hline Bank FE & Yes & Yes & No & Yes \\
\hline Country dummies & No & No & Yes & No \\
\hline Bank controls & No & No & Yes & No \\
\hline Constant & $\begin{array}{l}-0.0187 \\
(0.0126)\end{array}$ & $\begin{array}{l}-0.0204 * \\
(0.0119)\end{array}$ & $\begin{array}{l}-0.314 \\
(0.396)\end{array}$ & $\begin{array}{c}-0.0276 * * \\
(0.0133)\end{array}$ \\
\hline $\begin{array}{l}\mathrm{N} \\
\mathrm{R} 2\end{array}$ & $\begin{array}{c}7388 \\
0.0477\end{array}$ & $\begin{array}{c}7388 \\
0.0478\end{array}$ & 6187 & $\begin{array}{c}6187 \\
0.0583\end{array}$ \\
\hline
\end{tabular}

Standard errors in parentheses

${ }^{*} p<0.1,{ }^{* *} p<0.05,{ }^{* * *} p<0.01$

Notes: $\quad$ BidAsk $_{i t}=\beta_{1}$ Qend $_{t}+\beta_{2}$ Qend $_{t} \cdot L_{i t}+\delta_{1}$ Yend $_{t}+\theta_{1} w_{i t}^{N B}+\theta_{2} w_{i t}^{B I L}+\theta_{3} w_{i t}^{S R}+\delta_{2}$ Ctrl $_{i t}++\delta_{3}$ Ctrl $_{i t}$. Qend $_{t}+\delta_{4}$ Country $_{i}+\alpha_{i}+\gamma_{t}+\varepsilon_{i t}$. BidAsk $k_{i t}$ is the weighted average daily bid-ask spread applied by bank $i$ on day $t ; w_{i t}^{S R}$ is the share of special repo volume over total repo volume; end $_{t}$ is the dummy variable that indicates quarter-end; $L R_{i t}$ is the level of leverage ratio; Yend $_{t}$ is the year-end dummy controlling for year-end additional effects; and Country Cre dummy $_{i}$ variables that control for the jurisdiction of the borrowing bank. A trade takes a Qend (Yend) unit value if it is open (i.e. it may contribute to the bank's exposure) on the last trading day of each quarter (year). Hausman tests are run to check whether the use of random effects is possible. Special repo transactions are defined as follows: the repo rate of each ISIN is computed for each day. Those transactions whose rates are below the median rate of the collateral jurisdiction on each day are labelled as 'special'. The sample is made up of transactions in which for the same reporting bank, the same underlying security, on the same day, borrowing and lending volumes are very similar $\left(\frac{\mid \text { BorrVolume-LendVolume } \mid}{\text { BorrVolume }+ \text { LendVolume }}<5 \%\right)$. Cash borrowing and cash lending transactions are both CCP-cleared. The difference between the lending rate and the borrowing rate is then averaged (weighted by the transaction volume) at bank-date level in order to get the daily average bid-ask spread. 
Table 12: Net repo exposure - Non-banks

\begin{tabular}{|c|c|c|c|}
\hline & $\begin{array}{c}\text { (1) } \\
\text { Volume / TA }\end{array}$ & $\begin{array}{c}(2) \\
\text { Volume / TA }\end{array}$ & $\begin{array}{c}(3) \\
\text { Volume / TA }\end{array}$ \\
\hline$Q$-end & $\begin{array}{l}-0.0821 \\
(0.0497)\end{array}$ & $\begin{array}{l}-0.750 \\
(0.485)\end{array}$ & $\begin{array}{l}-0.874^{*} \\
(0.492)\end{array}$ \\
\hline$Q$-end $* L R$ & & $\begin{array}{l}-0.0516 \\
(0.0684)\end{array}$ & $\begin{array}{c}-0.0412 \\
(0.0648)\end{array}$ \\
\hline$Y$-end & $\begin{array}{l}0.0270 \\
(0.107)\end{array}$ & $\begin{array}{c}2.158 \\
(2.560)\end{array}$ & $\begin{array}{c}2.151 \\
(2.498)\end{array}$ \\
\hline$Q$-end controls & No & Yes & Yes \\
\hline$Y$-end controls & No & Yes & Yes \\
\hline Bank FE & Yes & No & Yes \\
\hline Country dummies & No & Yes & No \\
\hline Bank controls & No & Yes & No \\
\hline Constant & $\begin{array}{c}0.908 * * * \\
(0.000823)\end{array}$ & $\begin{array}{c}17.28 \\
(11.59)\end{array}$ & $\begin{array}{c}0.939 * * * \\
(0.000826)\end{array}$ \\
\hline $\begin{array}{l}\mathrm{N} \\
\mathrm{R} 2\end{array}$ & $\begin{array}{c}11428 \\
0.000436\end{array}$ & 10983 & $\begin{array}{c}10983 \\
0.00129\end{array}$ \\
\hline
\end{tabular}

Standard errors in parentheses
${ }^{*} p<0.1,{ }^{* *} p<0.05,{ }^{* * *} p<0.01$

Notes: $S_{i t}=\beta_{0}+\alpha_{i}+\beta_{1}$ Qend $_{t}+\beta_{2}$ Qend $_{t} \cdot L R_{i t}+\delta_{1}$ Yend $_{t}+\delta_{2}$ eend $_{t} \cdot$ Ctrl $_{i t}+\delta_{3}$ Ctrl $_{i t}+\delta_{4}$ Country $_{i}+\varepsilon_{i t} . S_{i t}$ is the LR-relevant net outstanding amount of repo borrowing from non-bank on any maturity by bank $i$ on day $t$; Qend $d_{t}$ is the dummy variable that indicates quarter-end; $L R_{i t}$ is the level of leverage ratio; $Y e n d_{t}$ is the year-end dummy controlling for year-end additional effects; and Country $y_{i}$ are dummy variables that control for the jurisdiction of the borrowing bank. A trade takes a Qend (Yend) unit value if it is open (i.e. it may contribute to the bank's exposure) on the last trading day of each quarter (year). Hausman tests are run to check whether the use of random effects is possible. 
Table 13: Net repo exposure - CCP-cleared

\begin{tabular}{|c|c|c|c|}
\hline & $\begin{array}{c}\text { (1) } \\
\text { Volume / TA }\end{array}$ & $\begin{array}{c}(2) \\
\text { Volume / TA }\end{array}$ & $\begin{array}{c}\text { (3) } \\
\text { Volume /TA }\end{array}$ \\
\hline Q-end & $\begin{array}{c}-0.323 * * * \\
(0.0947)\end{array}$ & $\begin{array}{c}-5.467 * * * \\
(1.074)\end{array}$ & $\begin{array}{c}-6.167 * * * \\
(1.014)\end{array}$ \\
\hline$Q$-end $* L R$ & & $\begin{array}{c}0.154 \\
(0.0947)\end{array}$ & $\begin{array}{l}0.212 * \\
(0.114)\end{array}$ \\
\hline$Y$-end & $\begin{array}{l}-0.0992 \\
(0.121)\end{array}$ & $\begin{array}{l}-1.270 \\
(1.284)\end{array}$ & $\begin{array}{l}-1.293 \\
(1.298)\end{array}$ \\
\hline$Q$-end controls & No & Yes & Yes \\
\hline$Y$-end controls & No & Yes & Yes \\
\hline Bank FE & Yes & No & Yes \\
\hline Country dummies & No & Yes & No \\
\hline Bank controls & No & Yes & No \\
\hline Constant & $\begin{array}{l}1.782 * * * \\
(0.00151)\end{array}$ & $\begin{array}{c}15.10 \\
(9.287)\end{array}$ & $\begin{array}{l}1.431 * * * \\
(0.00116)\end{array}$ \\
\hline $\begin{array}{l}\mathrm{N} \\
\mathrm{R} 2\end{array}$ & $\begin{array}{c}15845 \\
0.00309\end{array}$ & 13842 & $\begin{array}{c}13842 \\
0.0106\end{array}$ \\
\hline
\end{tabular}

Standard errors in parentheses
${ }^{*} p<0.1,{ }^{* *} p<0.05,{ }^{* * *} p<0.01$

Notes: $S_{i t}=\beta_{0}+\alpha_{i}+\beta_{1}$ Qend $_{t}+\beta_{2}$ Qend $_{t} \cdot L R_{i t}+\delta_{1}$ Yend $_{t}+\delta_{2}$ Qend $_{t} \cdot$ Ctrl $_{i t}+\delta_{3}$ Ctrl $_{i t}+\delta_{4}$ Country $_{i}+\varepsilon_{i t} \cdot S_{i t}$ is the LR-relevant net outstanding amount of repo borrowing from CCPs on any maturity by bank $i$ on day $t$; Qend $d_{t}$ is the dummy variable that indicates quarter-end; $L R_{i t}$ is the level of leverage ratio; Yend ${ }_{t}$ is the year-end dummy controlling for year-end

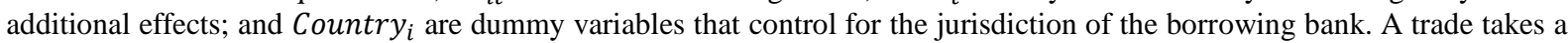
Qend (Yend) unit value if it is open (i.e. it may contribute to the bank's exposure) on the last trading day of each quarter (year). Hausman tests are run to check whether the use of random effects is possible. 
Table 14: Net repo exposure - Bilateral interbank

\begin{tabular}{|c|c|c|c|}
\hline & $\begin{array}{c}(1) \\
\text { Volume / TA }\end{array}$ & $\begin{array}{c}(2) \\
\text { Volume / TA }\end{array}$ & $\begin{array}{c}\text { (3) } \\
\text { Volume / TA }\end{array}$ \\
\hline$Q$-end & $\begin{array}{l}-0.0972 * \\
(0.0477)\end{array}$ & $\begin{array}{c}-1.168^{* *} \\
(0.521)\end{array}$ & $\begin{array}{c}-1.614 * * \\
(0.709)\end{array}$ \\
\hline$Q$-end $* L R$ & & $\begin{array}{l}-0.0378 \\
(0.0390)\end{array}$ & $\begin{array}{l}-0.0195 \\
(0.0416)\end{array}$ \\
\hline$Y$-end & $\begin{array}{c}0.135 \\
(0.0836)\end{array}$ & $\begin{array}{l}3.160^{*} \\
(1.888)\end{array}$ & $\begin{array}{c}3.101 \\
(1.831)\end{array}$ \\
\hline$Q$-end controls & No & Yes & Yes \\
\hline$Y$-end controls & No & Yes & Yes \\
\hline Bank FE & Yes & No & Yes \\
\hline Country dummies & No & Yes & No \\
\hline Bank controls & No & Yes & No \\
\hline Constant & $\begin{array}{c}0.610 * * * \\
(0.000716)\end{array}$ & $\begin{array}{l}-28.56 \\
(24.98)\end{array}$ & $\begin{array}{c}0.581 * * * \\
(0.000274)\end{array}$ \\
\hline $\begin{array}{l}\mathrm{N} \\
\mathrm{R} 2\end{array}$ & $\begin{array}{c}12483 \\
0.000339\end{array}$ & 11463 & $\begin{array}{c}11463 \\
0.00101\end{array}$ \\
\hline
\end{tabular}

Standard errors in parentheses

${ }^{*} p<0.1,{ }^{* *} p<0.05,{ }^{* * *} p<0.01$

Notes: $S_{i t}=\beta_{0}+\alpha_{i}+\beta_{1}$ Qend $_{t}+\beta_{2}$ Qend $_{t} \cdot L R_{i t}+\delta_{1}$ Yend $_{t}+\delta_{2}$ Qend $_{t} \cdot \operatorname{Ctrl}_{i t}+\delta_{3} \operatorname{Ctrl}_{i t}+\delta_{4} \operatorname{Country}_{i}+\varepsilon_{i t} . S_{i t}$ is the LR-relevant net outstanding amount of repo borrowing in the interbank bilateral market on any maturity by bank $i$ on day $t$; Qend $_{t}$ is the dummy variable that indicates quarter-end; $L R_{i t}$ is the level of leverage ratio; $Y e n d_{t}$ is the year-end dummy controlling for year-end additional effects; and Country $y_{i}$ are dummy variables that control for the jurisdiction of the borrowing bank. A trade takes a Qend (Yend) unit value if it is open (i.e. it may contribute to the bank's exposure) on the last trading day of each quarter (year). Hausman tests are run to check whether the use of random effects is possible. 


\section{References}

Allahrakha, M., Cetina, J., and Munyan, B. (2018), "Do higher capital standards always reduce bank risk? The impact of the Basel leverage ratio on the US triparty repo market". Journal of Financial Intermediation, 34, 3-16

Anbil, S., and Senyuz, Z. (2018). “The regulatory and monetary policy nexus in the repo market”. FEDS Working Paper No. $27-2018$

Baldo, L., Bucalossi, A., and Scalia, A. (2018). "Leverage ratio and central bank operations in the Euro Area”. Economic Notes, 47(1), 21-68

BCBS (2014), "Basel III leverage ratio framework and disclosure requirements", BCBS Standards, 12 January 2014

BCBS (2018), "Statement on leverage ratio window-dressing behaviour", Newsletter of the Basel Committee of Banking Supervision, 18 October 2018

BCBS (2019), "Revisions to leverage ratio disclosure requirements", June 2019

Behn, M., Mangiante G., Parisi L. and Wedow M. (2019), "Behind the scenes of the beauty contest: window dressing and the G-SIB framework", ECB Working Paper No. 2298, July 2019

Bicu, A., Chen, L., and Elliott, D. (2017), "The leverage ratio and liquidity in the gilt and repo markets". Bank of England Staff Working Paper No. 690, 3 November 2017

BIS (2018), "Window dressing: the case of repo market", Annual Economic Report 2018, Box IIIA

BIS (2019), "Euro repo market functioning: collateral is king", Quarterly Review, December 2019

Buch, C. M., Hilberg, B., and Tonzer, L. (2016). "Taxing banks: An evaluation of the German bank levy". Journal of banking \& finance, 72, 52-66

CGFS (2015), "Regulatory change and monetary policy", Committee on the Global Financial System Papers no. 54, May 2015

Coeuré (2017), "Asset purchases, financial regulation and repo market activity", Speech by Benoît Cœuré, Member of the Executive Board of the ECB, at the ERCC General Meeting on "The repo market: market conditions and operational challenges", Brussels, 14 November 2017

Coeuré (2018), “The future of central bank money”, Speech by Benoît Cœuré, Member of the Executive Board of the ECB, at the International Center for Monetary and Banking Studies, Geneva, 14 May 2018

Duffie, D., and Krishnamurthy, A. (2016). "Pass-through efficiency in the Fed's new monetary policy setting. In Designing Resilient Monetary Policy Frameworks for the Future". Federal Reserve Bank of Kansas City, Jackson Hole Symposium (pp. 1815-1847)

EBA (2018), “EBA Risk Dashboard - data as of Q4 2018”, 29 March 2019

ECB (2018), “The use of the Eurosystem's monetary policy instruments and its monetary policy implementation framework Q2 2016 - Q4 2017”, Occasional Paper Series No. 209, April 2018

EU Parliament (2019a), "Directive (EU) 2019/878 of the European Parliament and of the Council of 20 May 2019 amending Directive 2013/36/EU as regards exempted entities, financial holding companies, mixed financial holding companies, remuneration, supervisory measures and powers and capital conservation measures" 
EU Parliament (2019b), "Regulation (EU) 2019/876 of the European Parliament and of the Council of 20 May 2019 amending Regulation (EU) 575/2013 as regards the leverage ratio, the net stable funding ratio, requirements for own funds and eligible liabilities, counterparty credit risk, market risk, exposures to central counterparties, exposures to collective investment undertakings, large exposures, reporting and disclosure requirements, and Regulation (EU) 648/2012"

Grill, M., Jakovicka, J., Lambert, C., Nicoloso, P., Steininger, L., and Wedow, M. (2017), "Recent developments in euro area repo markets, regulatory reforms and their impact on repo market functioning”. ECB Financial Stability Review, No. 2, November 2017

International capital Market Association (ICMA), ICMA repo surveys 2018 and 2019

International Securities Lending Association - ISLA (2019), Securities Lending Market Report, September 2019

Munyan, B. (2017), "Regulatory arbitrage in repo markets". Office of Financial Research Working Paper, No. 15-22

Van Horen, N., and Kotidis, A. (2018). "Repo market functioning: the role of capital regulation". Centre for Economic Policy Research Discussion Paper DP13090, 30 July 2018 